\title{
THERMOCHRONOLOGY AND MATHEMATICAL MODELING OF THE FORMATION DYNAMICS OF RARE-METAL-GRANITE DEPOSITS OF THE ALTAI COLLISION SYSTEM
}

\author{
N. G. Murzintsev1, I. Yu. Annikova1, 2, 3, A. V. Travin'1, 2, 3, A. G. Vladimirov 1, 2, 3, \\ B. A. Dyachkov ${ }^{4}$, , V. I. Maslov6, T. A. Oitseva4, O. A. Gavryushkina1 \\ 1 V.S. Sobolev Institute of Geology and Mineralogy, Siberian Branch of RAS, Novosibirsk, Russia \\ 2 Novosibirsk State University, Novosibirsk, Russia \\ ${ }^{3}$ Tomsk State University, Tomsk, Russia \\ ${ }^{4}$ D. Serikbaev East Kazakhstan State Technical University, Ust-Kamenogorsk, Kazakhstan \\ ${ }^{5}$ LLP K.I. Satpayev Altai Geological and Environmental Institute, Ust-Kamenogorsk, Kazakhstan \\ ${ }^{6}$ LLP GEO.KZ, Ust-Kamenogorsk, Kazakhstan
}

\begin{abstract}
The article presents an event correlation of the Permian-Triassic granites of the Altai collision system, which are associated with industrial ore deposits and occurrences (Mo-W, Sn-W, Li-Ta-Be). The multi-system and multi-mineral isotope datings of igneous rocks and ore bodies (U/Pb, $\mathrm{Re} / \mathrm{Os}, \mathrm{Rb} / \mathrm{Sr}, \mathrm{Ar} / \mathrm{Ar}$-methods) suggest the postcollisional (intraplate) formation of ore-magmatic systems (OMS), the duration of which depended on the crustmantle interaction and the rates of tectonic exposure of geoblocks to the upper crustal levels.Two cases of the OMS thermal history are described: (1) Kalguty Mo-W deposit associated with rare-metal granite-leucogranites and ongonite-elvan dykes, and (2) Novo-Akhmirov Li-Ta deposit represented by topaz-zinnwaldite granites and the contemporary lamprophyre and ongonit-elvan dykes. For these geological objects, numerical modeling was carried out. The proposed models show thermal cooling of the deep magmatic chambers of granite composition, resulting in the residual foci of rare-metal-granite melts, which are known as the petrological indicators of industrial ore deposits (Mo-W, $\mathrm{Sn}-\mathrm{W}, \mathrm{Li}-\mathrm{Ta}-\mathrm{Be}$ ). According to the simulation results concerning the framework of a closed magmatic system with a complex multistage development history, the magmatic chamber has a lower underlying observable massif and a reservoir associated with it. A long-term magmatic differentiation of the parental melt (a source of rare-metal-granite melts and ore hydrothermal fluids) takes place in this reservoir.
\end{abstract}

Key words: rare-metal-granite deposit; thermochronology; the thermal history of ore-magmatic systems; mathematical modeling; numerical simulation; Kalguty Mo-W deposit; Novo-Akhmirov Li-Ta deposit; Altai

For citation: Murzintsev N.G., Annikova I.Yu., Travin A.V., Vladimirov A.G., Dyachkov B.A., Maslov V.I., Oitseva T.A., Gavryushkina O.A., 2019. Thermochronology and mathematical modeling of the formation dynamics of rare-metal-granite deposits of the Altai collision system. Geodynamics \& Tectonophysics 10 (2), 375-404. doi:10.5800/GT-2019-10-2-0419. 


\title{
ТЕРМОХРОНОЛОГИЯ И МАТЕМАТИЧЕСКОЕ МОДЕЛИРОВАНИЕ ДИНАМИКИ ФОРМИРОВАНИЯ РЕДКОМЕТАЛЛЬНО-ГРАНИТНЫХ МЕСТОРОЖДЕНИЙ АЛТАЙСКОЙ КОЛЛИЗИОННОЙ СИСТЕМЫ
}

\author{
Н. Г. Мурзинцев 1 , И. Ю. Анникова $1,2,3$, А. В. Травин $1,2,3$, А. Г. Владимиров 1, 2, 3, \\ Б. А. Дьячков ${ }^{4,5}$, В. И. Маслов ${ }^{6}$, Т. А. Ойцева ${ }^{4}$, О. А. Гаврюшкина ${ }^{1}$ \\ ${ }^{1}$ Институт геологии и минералогии им. В.С. Соболева СО РАН, Новосибирск, Россия \\ ${ }^{2}$ Новосибирский национальный исследовательский государственный университет, \\ Новосибирск, Россия \\ 3 Томский государственный университет, Томск, Россия \\ ${ }^{4}$ Восточно-Казахстанский государственный технический университет им. Д. Серикбаева, \\ Усть-Каменогорск, Казахстан \\ 5 ТОО Алтайский геолого-экологический институт им. К.И. Сатпаева, \\ Усть-Каменогорск, Казахстан \\ ${ }^{6}$ TOO GEO.KZ, Усть-Каменогорск, Казахстан
}

\begin{abstract}
Аннотация: В статье проведена событийная корреляция пермотриасовых гранитов Алтайской коллизионной системы, с которыми связаны промышленные месторождения и рудопроявления (Mo-W, Sn-W, Li-Ta-Be). Мультисистемное и мультиминеральное изотопное датирование магматических пород и рудных тел (U/Pb, $\mathrm{Re} / \mathrm{Os}, \mathrm{Rb} / \mathrm{Sr},{ }^{40} \mathrm{Ar} /{ }^{39} \mathrm{Ar}$ - методы) указывает на постколлизионное (внутриплитное) формирование рудномагматических систем, длительность существования которых зависела от корово-мантийного взаимодействия и скорости тектонического экспонирования геоблоков на верхние уровни земной коры. Рассмотрены термические истории двух PMC: 1) Калгутинского Mo-W месторождения, связанного с редкометалльными гранит-лейкогранитами и онгонит-эльвановыми дайками, 2) Ново-Ахмировского Li-Та месторождения, представленного топаз-циннвальдитовыми гранитами, и связанными с ним во времени лампрофирами и онгонит-эльвановыми дайками. Для этих геологических объектов проведено численное моделирование и построены модели термического остывания глубинных магматических камер гранитного состава, приводящие к остаточным очагам редкометалльно-гранитных расплавов - петрологических индикаторов промышленных месторождений (Mo-W, Sn-W, Li-Ta-Be). Результаты моделирования показывают, что в рамках замкнутой системы со сложной многостадийной историей должен существовать нижний, подстилающий магматический резервуар. В этом резервуаре происходит длительная дифференциация родоначальной магмы, которая является источником редкометалльно-гранитных остаточных расплавов и рудных гидротермальных флюидов.
\end{abstract}

Ключевые слова: редкометалльно-гранитное месторождение; термохронология; термическая история рудно-магматических систем; математическое моделирование; Калгутинское Mo-W месторождение; Ново-Ахмировское Li-Tа месторождение; Алтай

\section{1. ВВЕДЕНИЕ}

Термохронологический подход является информативным для объектов со сложной, многостадийной термической историей, что относится к редкометалльно-гранитным рудно-магматическим системам (РМC), формирование которых происходило на уровнях мезоабиссальной и абиссальной фаций глубинности ( $\mathrm{h} \geq 10-15$ км). Длительные интервалы формирования (десятки миллионов лет) установлены для таких объектов, как граниты ВосточноАзиатского оловянного пояса [Cobbing et al., 1986], Корнубийский батолит [Darbyshire, Shepherd, 1994], Рудные горы в Чехии [Štemprock et al., 2005], Возне- сенская РМС в Приморье [Gonevchuk, 2002; Rub, Rub, 2006], редкометалльные граниты и сподуменовые пегматиты Калба-Нарымской зоны (Восточный Казахстан) [Dyachkov, 2012; Vladimirov et al., 2012; Khromykh et al., 2016; Oitseva et al., 2016a] и Забайкалья [Zagorsky et al., 2014; Antipin et al., 2016, 2018]. Расшифровка механизмов формирования редкометалльно-гранитных РМС являлась главной целью предпринятого исследования.

Статья посвящена термохронологии и численному моделированию термической истории Калгутинской Mo-W PMC и Ново-Ахмировской Li-Ta PMC [Dyachkov et al., 2017; Annikova et al., 2019; Oitseva, 2018]. 


\section{2. СОБЫТИЙНАЯ КОРРЕЛЯЦИЯ ПЕРМОТРИАСОВЫХ ГРАНИТОВ АЛТАЯ}

Редкометалльные граниты Алтайской коллизионной системы (АКС) привлекают пристальное внимание исследователей [Dergachev et al., 1981; Dergachev, 1988, 1989; Vladimirov et al., 1997, 2003, 2008, 2016; Annikova et al., 2006, 2016; Dyachkov, 2012; Dyachkov et al., 2017; Khromykh et al., 2014; Kruk, 2015; Gavryushkina et al., 2017, 2019]. Эта территория относится к западному сектору Центрально-Азиатского подвижного пояса, тектоническое строение и магматическая эволюция которого охарактеризована в работах [Sengör et al., 1993; Buslov et al., 2003, 2013; Vladimirov et al., 2001, 2003, 2008, 2016; Windley et al., 2007; Berzin, Kungurtsev, 1996; Safonova, 2014; Kruk, 2015; Kuibida et al., 2016, 2019; Ermolov et al., 1977, 1981, 1983; Ermolov, 2013; Travin et al., 2001, 2016; Lopatnikov et al., 1982; Shcherba et al., 1984, 1998; Kotler et al., 2015; Khromykh et al., 2016] (рис. 1).

Сводка геохронологических данных, полученных для пермотриасовых магматических комплексов АКС, приведена в таблице 1 . В сравнении предыдущими обзорными монографиями и статьями [Lopatnikov et al., 1982; Shcherba et al., 1998; Shokalsky et al., 2000; Vladimirov et al., 2001; Travin et al., 2001; Annikova et al., 2006; Potseluev et al., 2008; Dyachkov, 2012; Ermolov, 2013] здесь приведены новейшие оценки $\mathrm{U} / \mathrm{Pb}, \mathrm{Rb} / \mathrm{Sr}$ и ${ }^{40} \mathrm{Ar} /{ }^{39} \mathrm{Ar}$ изотопных возрастов, которые свидетельствуют о двух магматических (интрузивных) мегаритмах, проявившихся на территории АКС в позднем палеозое - раннем мезозое (рис. 2). В региональном плане эти рудномагматические системы разделены Иртышским литосферным разломом, то есть представляют собой автономные магматические очаговые ареалы (петрографические провинции).

\section{3. ГЕОЛОГИЧЕСКИЕ ОБЪЕКТЫ}

\section{1. КАЛГУТИНСКАЯ МО-W РМС (ГОРНЫЙ АЛТАЙ)}

Калгутинская РМС представлена одноименным гранитным батолитом $\left(\mathrm{S}=70 \mathrm{KM}^{2}\right.$, на современном эрозионном срезе, $\mathrm{V}=12800$ км$^{3}$ по геолого-геофизическим данным [Potseluev et al., 2008]). Этот батолит прорван Восточно-Калгутинским поясом редкометалльных онгонит-эльвановых даек, которые сопряжены в пространстве и времени с одноименным кварцево-жильно-грейзеновым Мо-W месторождением [Annikova et al., 2006]. Таким образом, Калгутинская PMC представляет собой классический пример гранитоидного батолита, с которым связано Mo-W месторождение. Формирование Калгутинской РМС относится к внутриплитному этапу и, как следствие, связано с активизацией сдвиговораздвиговых деформаций литосферы под воздействием Сибирского суперплюма [Vladimirov et al., 1997, 1998; Dobretsov et al., 2005] (рис. 3). Характеристика магматических комплексов и рудных образований Калгутинской PMC представлена в многочисленных публикациях [Dergachev et al., 1981; Dergachev, 1988; Vladimirov et al., 1997, 1998; Titov et al., 2001; Annikova et al., 2006; Potseluev et al., 2008; Sokolova et al., 2011; Gusev, 2011; Vladimirov et al., 2019].

Магматические комплексы Калгутинской РМС включают одноименный массив редкометалльных биотитовых и двуслюдяных крупнозернистых порфировидных гранитов главной интрузивной фазы $\left(Г \Phi^{*}\right)$, интрузивные штоки мусковитовых, двуслюдяных и турмалинсодержащих лейкогранитов и Восточно-Калгутинский онгонит-эльвановый дайковый пояс протяженностью 10-15 км при ширине около 3 км, в пределах которого закартировано 125 онгонитовых и эльвановых даек мощностью от десятков сантиметров до первых метров [Annikova et $a l ., 2006]$. Граниты ГФ отвечают умеренно-глиноземистым составам нормальной щелочности, при переходе к лейкогранитам происходит увеличение коэффициента глиноземистости и суммарной щелочности, породы дайкового пояса отвечают высокоглиноземистым субщелочным составам [Annikova et al., 2006; Vladimirov et al., 2019]. В гранитах главной фазы и лейкогранитах содержания фтора (0.07-0.10 мас. \%) и $\mathrm{P}_{2} \mathrm{O}_{5}$ (0.16-0.26 мас. \%) близки к кларковым для гранитоидов [Tauson, 1977]. Породы дайкового пояса имеют специфический химический состав. Для них характерны невысокие для литий-фтористой фации гранитоидов содержания фтора (не более 0.5 мас. \%) при аномальных содержаниях $\mathrm{P}_{2} \mathrm{O}_{5}$ (до 0.96 мас. \%) на фоне высокого содержания редких щелочных элементов $(\Sigma \mathrm{Li}, \mathrm{Rb}$, Cs 0.5 мас. \%). Главные вкрапленники в этих гранитоидах - калиевый полевой шпат, альбит, кварц, мусковит, в единичных дайках - биотит, в подчиненных, но в значительных количествах встречается апатит. Среди акцессорных минералов диагностированы пирит, циркон, монацит, танталитколумбит, ксенотим, вольфрамит, монтебразит, гердерит, магнетит [Titov et al., 2001; Annikova et al., 2016; Sokolova et al., 2011]. Особое место занимает Центральная дайка, в пределах которой зафиксированы фациальные переходы между существенно натровыми $\left(\mathrm{Na}_{2} \mathrm{O}>\mathrm{K}_{2} \mathrm{O}\right)$ и существенно калиевыми $\left(\mathrm{K}_{2} \mathrm{O}>\mathrm{Na}_{2} \mathrm{O}\right)$ разновидностями онгонитов,

\footnotetext{
* Здесь и ниже по тексту приняты сокращения по КоптевуДворникову: ГФ - главная интрузивная фаза, ФДи - фаза дополнительных интрузий, ЗФ - заключительная фаза гранитоидных батолитов.
} 


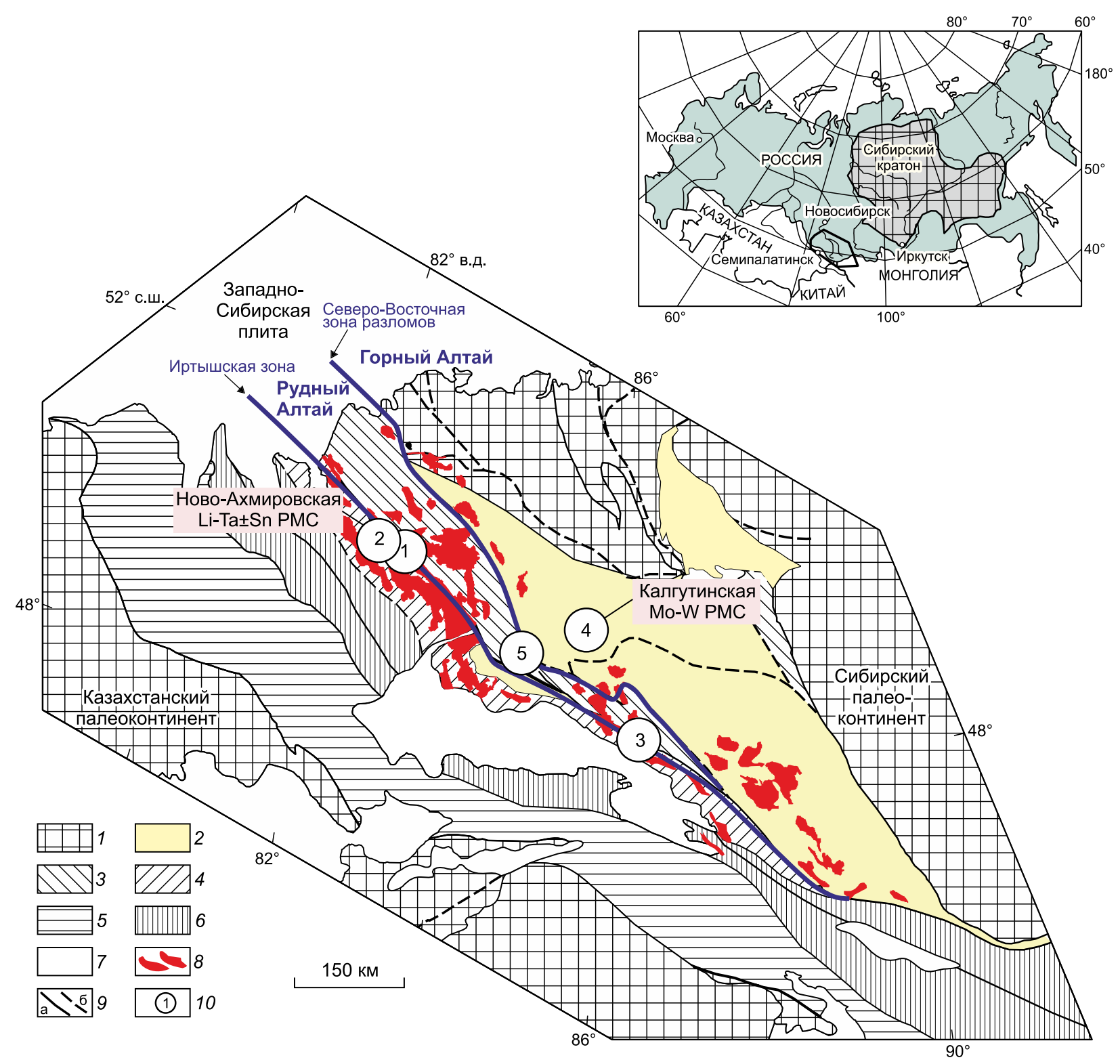

Рис. 1. Геотектоническая схема Калба-Нарым-Коктогайского редкометалльного пояса (Li-Rb-Cs, Ta-Nb, Sn-W), литиеносных онгонит-эльвановых дайковых поясов и интрузивных штоков топаз-циннвальдитовых гранитов. Составлена по материалам [Vladimirov et al., 2003; Annikova et al., 2016], с дополнениями.

Алтайская аккреционно-коллизионная система: 1 - неопротерозойские - раннепалеозойские структурно-вещественные комплексы Сибирского и Казахстанского палеоконтинентов; 2 - Алтае-Монгольский микроконтинент; 3-6 - окраинно-континентальные и океанические террейны средне- и позднепалеозойского возраста: 3 - Рудно-Алтайский островодужный, 4 - КалбаНарымский турбидитовый, 5 - Жарма-Саурский островодужный, 6 - Чарский океанический; 7 - кайнозойские отложения; 8 гранитоидные батолиты в возрастном диапазоне от карбона до ранней юры включительно; 9 - разломы (достоверные (а) и предполагаемые (б)); 10 - геологические объекты (1 - сподуменовые пегматиты Асубулакского Li-Ta-Be месторождения, 2 - онгониты и литий-фтористые граниты центральной части Калба-Нарымского гранитоидного батолита, 3 - сподуменовые пегматиты Коктогайского Li-Ta-Be месторождения, 4 - онгонит-эльваны Калгутинского Mo-W месторождения, 5 - сподуменовые гранит-порфиры Алахинского Li-Tа месторождения).

Fig. 1. Geotectonic scheme of the Kalba-Narym-Koktogay rare metal belt (Li-Rb-Cs, Ta-Nb, Sn-W), lithium-bearing ongoniteelvan diyke belts and intrusive stocks of topaz-zinnvaldite granites. Compiled from [Vladimirov et al., 2003; Annikova et al., 2016] with additions.

The Altai accretion-collision system: 1 - Neoproterozoic - Early Paleozoic structural-substance complexes of the Siberian and Kazakhstan paleocontinents; 2 - Altai-Mongolian microcontinent; 3-6-marginal-continental and oceanic terrains of Middle-Late Paleozoic: 3-Rudny Altai island-arc terrane, 4 - Kalba-Narym turbidite terrane, 5 - Zharma-Saur island arc terrane, 6 - Charsky oceanic terrane; 7 - Cenozoic sediments, 8 - granitoid batolites in the age range from Carboniferous to Early Jurassic inclusively; 9 - reliable (a) and assumed (б) faults; 10 - geological objects: 1 - spodumene pegmatites of the Asubulak Li-Ta-Be deposit, 2 - ongonites and lithium-fluorine granites of the central part of the Kalba-Narym granitoid batholith, 3 - spodumene pegamitites of the Kogtogay Li-Ta-Be deposit, 4 - ongonite-elvan of the Kalguty Mo-W deposit, 5 - spodumene granite porphyries of the Alakha Li-Ta deposit. 


\section{Т а б л и ц а 1. Сводка геохронологических данных, полученных для пермотриасовых магматических} комплексов Алтайской коллизионной системы

$\mathrm{T}$ a b l e 1. The geochronological summary for the Perm-Triassic magmatic complexes of the Altai collision system

\begin{tabular}{llll}
\hline Массив, порода & Метод, минерал & Возраст, млн лет & Источник
\end{tabular}

\section{Калба-Нарымская зона, Восточный Казахстан}

Раннекалбинский гранодиорит-гранит-лейкогранитный комплекс

Асубулакский массив, граниты

$\mathrm{U}-\mathrm{Pb}$, метод LA-SF-ICP-MS, Zrn $\mathrm{Ar}-\mathrm{Ar}, \mathrm{Bt}$

Черновинский массив: $\mathrm{U}-\mathrm{Pb}$, метод LA-SF-ICP-MS, Zrn гранодиориты, граниты $\mathrm{Ar}-\mathrm{Ar}, \mathrm{Bt}$

Асубулакский сподумен-пегматитовый комплекс

Месторождения Асубулак,

Ar-Ar, Ms, Lpd

Белогорское, Огневка:

сподуменовые пегматиты

Позднекалбинский гранит-лейкогранитный комплекс

Шибендинский, Черновинский,

$\mathrm{U}-\mathrm{Pb}$, метод LA-SF-ICP-MS, Zrn

Миролюбовский, Сергеевский,

Кемиркаинский массивы: граниты- $\mathrm{Ar}-\mathrm{Ar}, \mathrm{Bt}, \mathrm{Ms}$

лейкограниты

Монастырский гранит-лейкогранитный комплекс

Войлочевский массив:

$\mathrm{U}-\mathrm{Pb}$, метод LA-SF-ICP-MS, Zrn

лейкограниты

Ar-Ar, Bt

$\mathrm{U}-\mathrm{Pb}$, SHRIMP II, Zrn

Монастырский, Сибинский,

$\mathrm{Ar}-\mathrm{Ar}, \mathrm{Bt}$

Войлочевский, Каиндинский

Миролюбовский массивы:

лейкограниты

Миролюбовский онгонит-лампрофир-долеритовый дайковый комплекс

Дайка, секущая Черновинский

Ar-Ar, Amf

Ar-Ar, Ms

Чечекский дайковый пояс:

онгониты

$\mathrm{Rb}-\mathrm{Sr}, \mathrm{W}-\mathrm{Ms}$

Ar-Ar, Bt

Дайка, секущая Монастырский

гранит-лейкогранитный массив:

спессартиты

Ново-Ахмировская рудно-магматическая система

Ново-Ахмировский шток:

$\mathrm{Rb}-\mathrm{Sr}, \mathrm{W}-\mathrm{Lpd}$

топаз-циннвальдитовые граниты

(обр. KT-1/4)

Ar-Ar, Zwd (обр. ВК-16-60)

\section{Горный и Рудный Алтай, Россия-Казахстан}

Айский сиенит-граносиенит-лейкогранитовый комплекс

Айский массив, $\mathrm{Ar}-\mathrm{Ar}, \mathrm{Bt}$

$272 \pm 4$

$272.4 \pm 2.4$

$250 \pm 3$

$281.2 \pm 2.3$

$284.2 \pm 3.8$

$285 \pm 3-271 \pm 3$

$279 \pm 3$

$285 \pm 3$

$266 \pm 7$

$267 \pm 1$

[Kotler et al., 2015]

[Khromykh et al., 2016]

»

[Oitseva et al., 2016a, 2016b]

[Khromykh et al., 2016]

[Kotler et al., 2015]

[Khromykh et al., 2016]

[Khromykh et al., 2016]

[Kotler et al., 2015]

[Khromykh et al., 2016]

[Khromykh et al., 2016]

[Khromykh et al., 2018]

[Khromykh et al., 2014]

[Dovgal et al., 1995]

[Dovgal et al., 1995]

[Annikova et al., 2019]

[Gavryushkina et al., 2016]

Белокурихинский гранит-лейкогранитовый комплекс

$\begin{array}{lll}\text { Белокурихинский массив, граниты } & \mathrm{Ar}-\mathrm{Ar}, \mathrm{Bt} & 250 \pm 3 \\ \text { Осокинский шток, лейкограниты } & \mathrm{Ar}-\mathrm{Ar}, \mathrm{Ms} & 250 \pm 3 \\ \text { Точильненский шток, пегматиты } & \mathrm{Ar}-\mathrm{Ar}, \mathrm{Ms} & 247 \pm 3 \\ \text { Верхнешебетинский массив, } & \mathrm{Ar}-\mathrm{Ar}, \mathrm{Ms} & 241 \pm 3\end{array}$

лейкограниты

$\mathrm{Ar}-\mathrm{Ar}, \mathrm{Ms}$

$241 \pm 3$

Синюшенский гранодиорит-гранит-лейкогранитовый комплекс

Синюшенский массив,

лейкограниты

Саввушинский массив,

граниты
$\mathrm{Ar}-\mathrm{Ar}, \mathrm{Bt}$

$\mathrm{Ar}-\mathrm{Ar}, \mathrm{Bt}$
$248 \pm 1$

$244 \pm 1$ $\gg$

》 
N.G. Murzintsev et al.: Thermochronology and mathematical modeling of the formation dynamics...

Т а б л и ц а 1 (окончание)

T a b l e 1 (end)

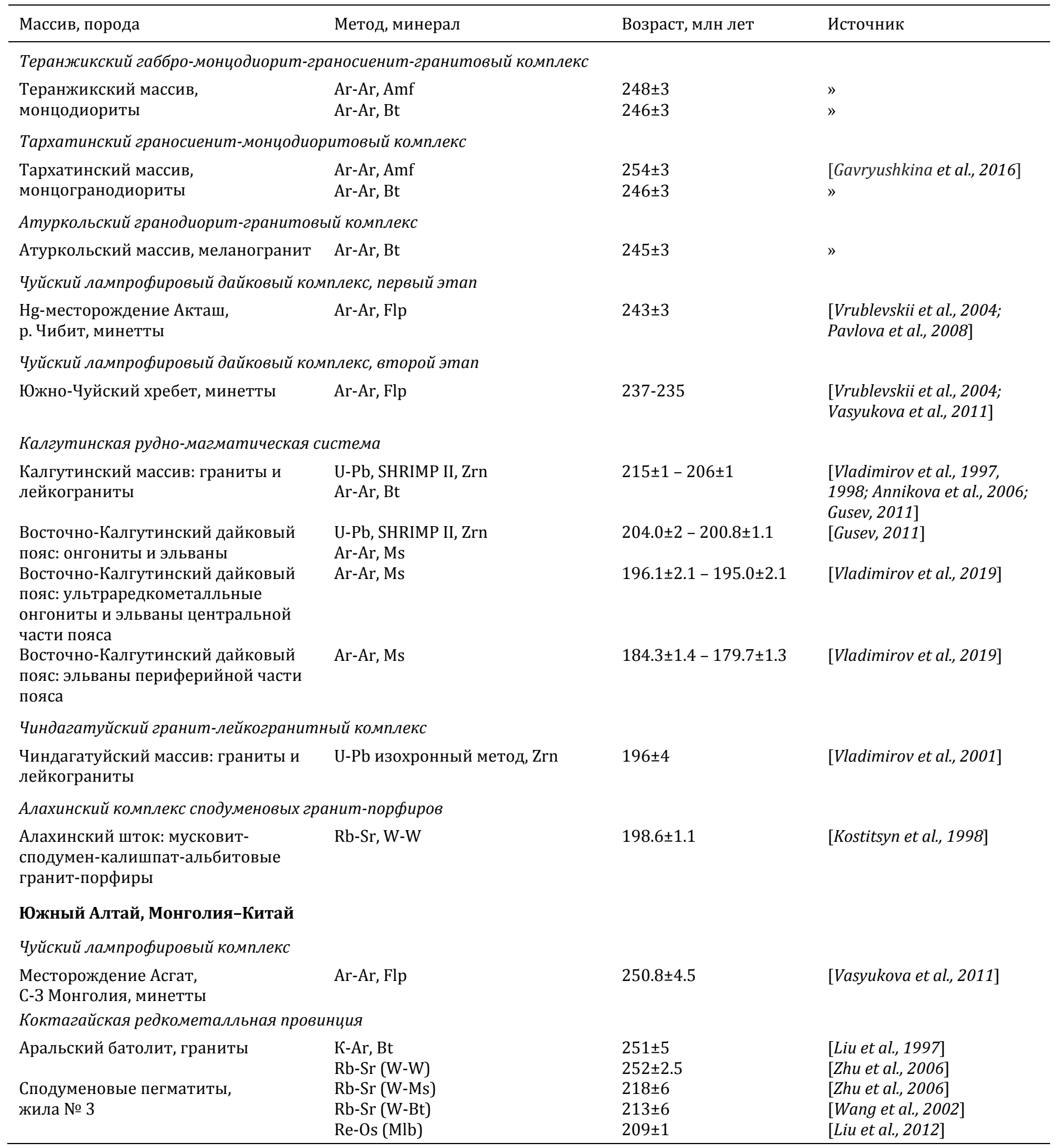

П р и м е ч а н и е. В данной таблице не приводятся геохронологические данные по магматическим комплексам позднекаменноугольно-раннепермского возраста (310-295 млн лет), которые отвечают раннеколлизионной геодинамической обстановке и достаточно полно охарактеризованы в [Vladimirov et al., 2016; Kuibida et al., 2019]. Условные сокращения: W-W - вал, Zrn - циркон, $\mathrm{Ms}$ - мусковит, Bt - биотит, Lpd - лепидолит, Amf - амфибол, Zwd - циннвальдит, Flp - флогопит, Мlb - молибденит.

$\mathrm{N}$ o t e. This table does not contain geochronological data on the magmatic complexes of the late Carboniferous and Early Permian (310-295 Ma), which correspond to the early collision geodynamic setting (see this data in [Vladimirov et al., 2016; Kuibida et al., 2019]). Legend: W-W - whole rock, Zrn - zircon, Ms - muscovite, Bt - biotite, Lpd - lepidolite, Amf - amphibole, Zwd - zinnwaldite, Flp - phlogopite, Mlb - molybdenite. 


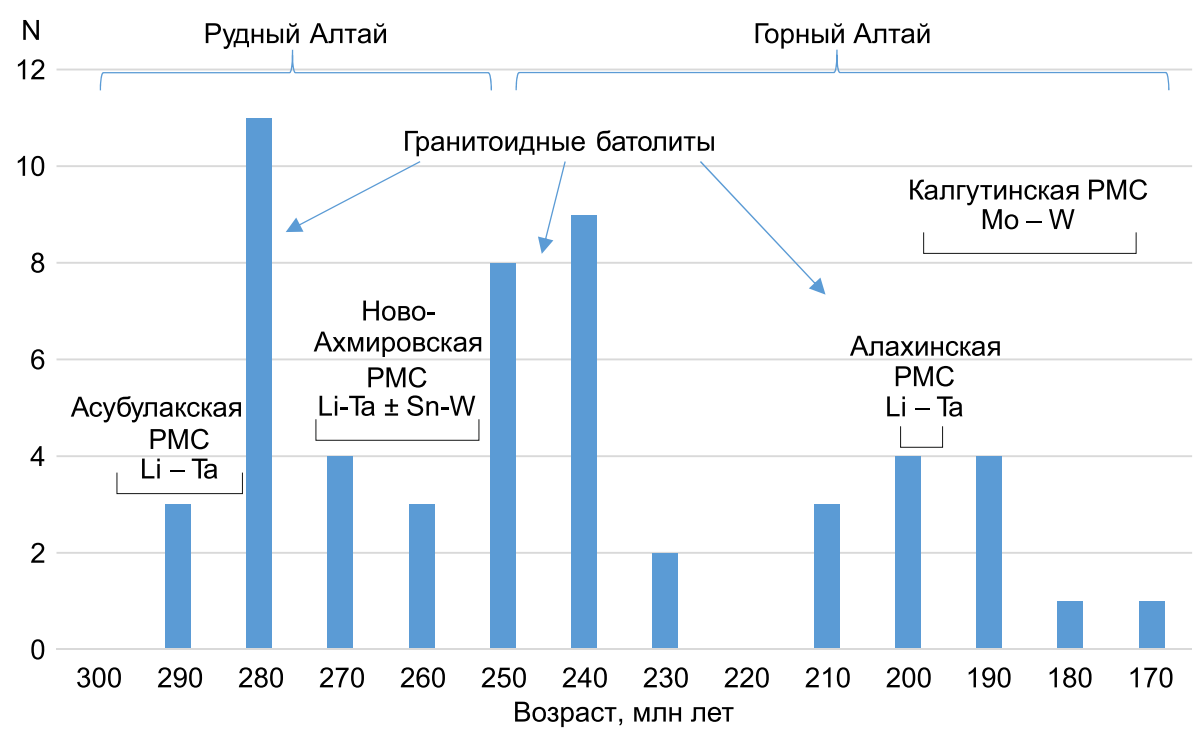

Рис. 2. Гистограмма распределения геохронологических возрастов в пермотриасовых магматических комплексах Алтайской коллизионной системы (АКС). N - число изотопных возрастов. На гистограмму вынесены статистически значимые оценки возрастов промышленных месторождений редких элементов (Li-Ta-Nb, Sn-W, W-Mo), пояснения в тексте.

Fig. 2. Geochronological age distribution histogram for the Permian-Triassic magmatic complexes of the Altai collision system (ACS). $\mathrm{N}$ is the number of isotopic ages. The histogram contains statistically significant estimates of the ages of rareelements commercial deposits (Li-Ta-Nb, Sn-W, Wo-Mo). See explanations in the text.

при этом по уровням концентрации редких щелочных элементов (Li, Rb, Cs) калиевые разновидности относятся к высокоредкометалльным, а натровые к ультраредкометалльным, подчеркивая, таким образом, гетерогенность состава как дайкового пояса в целом, так и отдельных даек, и, одновременно, - их генетическое родство как продуктов дифференциации единой родоначальной магмы в глубинном очаге [Annikova et al., 2006; Sokolova et al., 2011; Vladimirov et al., 2019]. По геологическим наблюдениям в горных выработках Калгутинского Mo-W месторождения было зафиксировано, что кварцевые жилы главного рудопродуктивного этапа пересекаются дайками эльванов и онгонитов, и лишь в редких случаях наблюдается обратная картина, на этом основании сделан вывод о «внутрирудном» характере даек и их тесной пространственно-временной сопряженности с рудной гидротермальной системой [Annikova et al., 2006, 2007].

Общая сводка геохронологических данных по Калгутинской РМС приведена в таблице 2. Термохронограмма геологических событий в координатах «температура - возраст закрытия радиогенных систем», позволяющая оценить статистические пики возрастов, представлена на рисунке 4. Синтез геологических, петрогенетических и геохронологических исследований (U/Pb - циркон, Re/Os - молибденит, ${ }^{40} \mathrm{Ar} /{ }^{39} \mathrm{Ar}$ - биотит, мусковит) позволил реконструировать термохронологическую историю формирования Калгутинской РМС, включающую пять этапов

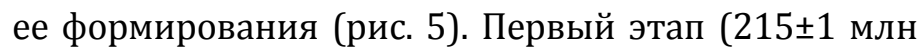
лет) отвечает формированию гранитов главной интрузивной фазы и богатого молибденового оруденения, представленного рудным телом, именуемым Молибденовый шток. Второй этап (206ะ1 млн лет) связан с формированием штоков лейкогранитов и внутригранитных пегматитов в гранитах главной интрузивной фазы. Третий этап (202ะ1 млн лет) онгонит-эльвановый, его временной диапазон соответствует формированию большинства даек, слага-

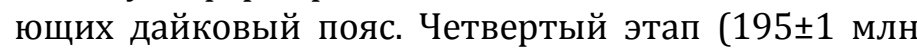
лет) отвечает формированию ультраредкометалльных протяженных даек онгонитов и эльванов, локализованных в центральной части дайкового пояса, пространственно совмещенной с богатыми вольфрамовыми жилами месторождения. Пятый этап

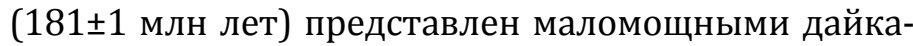
ми онгонитов и эльванов на периферии дайкового пояса. Таким образом, общая продолжительность рудно-магматических процессов при формировании Калгутинской РМС составляет 20 млн лет (Mo-W pyдопродуктивный этап) и 30 млн лет, если учитывать единичные эльвановые дайки по периферии Калгу-

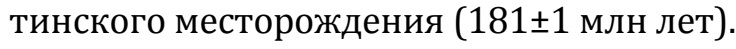

\section{2. НОВО-АХМИРОВСКАЯ LI-TA PMC (РУДНЫЙ АЛТАЙ)}

Структурно-геологическая схема расположения онгонитовых даек и литий-фтористых гранитов в центральной части Калба-Нарымской зоны приве- 


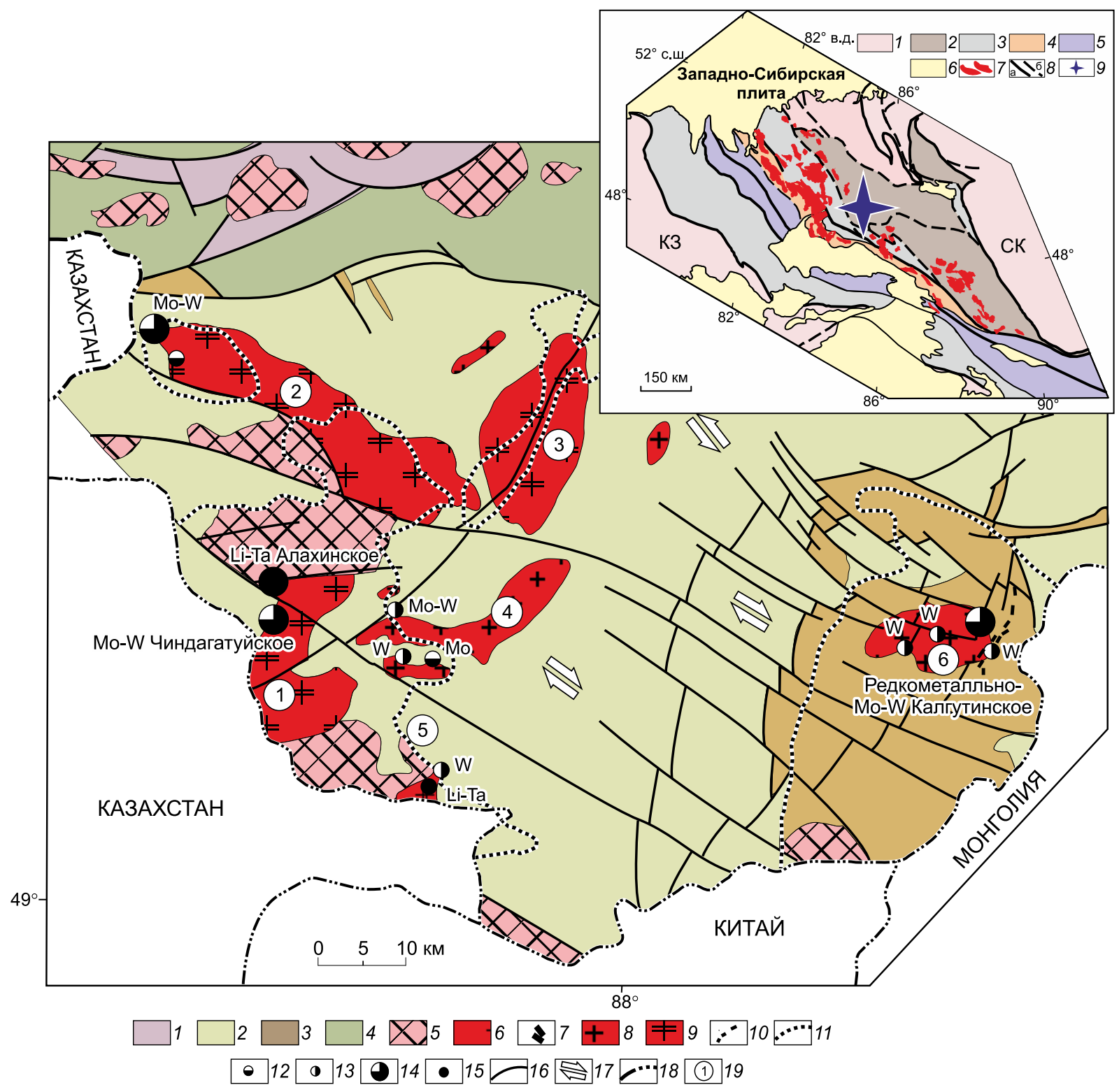

Рис. 3. Схема расположения позднепалеозойских - раннемезозойских гранитоидных батолитов и редкометалльных месторождений в геологических структурах южной части Горного Алтая (по [Vladimirov et al., 1997, 2003; Shokalsky et al., 2000; Annikova et al., 2006], с изменениями).

1 - структурно-вещественные комплексы венд-раннекембрийской аккреционной призмы Горного Алтая; 2-4 - Холзунско-Чуйский террейн в составе Алтае-Монгольского микроконтинента: 2 - нижний структурный этаж, представленный турбидитовыми толщами раннепалеозойского возраста, 3 - верхний структурный этаж, представленный осадочно-вулканогенными толщами среднепалеозойского возраста, 4 - коллизионный шов, представленный южно-чуйским метаморфическим комплексом (PZ1:PZ2); 5 - среднепалеозойские коллизионные гранитоиды, имеющие известково-щелочной состав в пределах Холзунско-Чуйского террейна и монцонитоидный в пределах Южно-Чуйского коллизионного шва; 6-10 - раннемезозойские магматические комплексы, относящиеся к внутриплитному этапу тектогенеза: 6 - гранит-лейкограниты кунгурджаринского комплекса ( $\left.\mathrm{T}_{2} \mathrm{~kg}\right), 7$ - лампрофиры и щелочные базальты чуйского комплекса ( $\left.\mathrm{T}_{2} \mathrm{č}\right), 8$ - гранит-лейкограниты калгутинского комплекса ( $\mathrm{T}_{3}$-J $\left.\mathrm{k}_{1} \mathrm{kl}\right), 9$ - гранитлейкограниты чиндагатуйского комплекса (Jičn), 10 - гранит-порфиры, эльваны и онгониты восточно-калгутинского комплекca (J v v ); 11- контуры Бухтарминского (на западе) и Калгутинского (на востоке) очаговых ареалов раннепалеозойского возраста, проведенные с учетом отрицательных аномалий остаточного гравитационного поля; 12-15 - редкометалльные гидротермальные и магматогенные рудопроявления и месторождения: 12 - существенно молибденовые, 13 - существенно вольфрамовые, 14 - молибден-вольфрамовые, 15 - литий-танталовые; 16 - раннемезозойские разломы сдвигового и взбросо-сбросового характера; 17 - преобладающая кинематика сдвигов в различных геоблоках (литонах); 18 - государственные границы; 19 - номера массивов: 1 - Чиндагатуйский, 2 - Орочаганский, 3 - Акалахинский, 4 - Текекундейский, 5 - Кунгурджаринский, 6 - Калгутинский.

Врезка: Алтайская аккреционно-коллизионная система [Vladimirov et al., 2003, 2008]. 1 - неопротерозойские - раннепалеозойские структурно-вещественные комплексы Сибирского и Казахстанского палеоконтинентов; 2 - Алтае-Монгольский микроконтинент; 3 - Рудно-Алтайский островодужный террейн; 4 - Калба-Нарымский турбидитовый террейн; 5 - Чарский океанический террейн; 6 - кайнозойские отложения; 7 - гранитоидные батолиты в возрастном диапазоне от карбона до ранней юры включительно; 8 - разломы (достоверные (а) и предполагаемые (б)); 9 - Калгутинская Mo-W PMC. 
Fig. 3. Schematic map showing the locations of the late Paleozoic-early Mesozoic granitoid batolites and rare-metal deposits in the geological structures of the southern Altai mountains (modified after [Vladimirov et al., 1997, 2003; Shokalsky et al., 2000; Annikova et al., 2006]).

1 - structural-substance complexes of the Vendian - Early Cambrian accretionary prisms of Gorny Altai; 2-4 - Kholzun-Chuya terrain, a part of the Altai-Mongolian microcontinent: 2 - lower structural level (Early Paleozoic turbidite strata), 3 - upper structural level (Middle Paleozoic sedimentary-volcanogenic strata), 4 - collisional suture (South Chuysky metamorphic complex, PZ1:PZ2); 5 - Middle Paleozoic collisional granitoids of the calc-alkaline composition within the Kholzyn-Chuya terrane and of the monzonitoid composition within the South Chuya collisional suture; 6-10 - Early Mesozoic magmatic complexes related to the intraplate stage of tectogenesis: 6 - graniteleucogranites of the Kungurdjarin complex $\left(\mathrm{T}_{2} \mathrm{~kg}\right), 7$ - lamprophyre and alkaline basalts of the Chuya complex ( $\left.\mathrm{T}_{2} \mathrm{c}\right), 8$ - graniteleucogranites of the Kalguty complex ( $\left.\mathrm{T}_{3}-\mathrm{J}_{1} \mathrm{kl}\right), 9$ - granite-leucogranites of the Chindagatuy complex (J 1 čn), 10 - granite-porphyries, ongonites and elvan of the East Kalguty complex (J1vk); 11 - contours of the Bukhtarma (west) and Kalguty (east) focal areas of the Early Paleozoic, taking into account the negative anomalies of the residual gravitational field; 12-15 - rare-metal hydrothermal and magmatogenic ore occurrences and deposits: 12 - substantially molybdenum, 13 - substantially tungsten, 14 - molybdenum-tungsten, 15 - lithiumtantalum; 16 - Early Mesozoic shear and upthrust faults; 17 - shifting dominating in geoblocks (lithons); 18 - state border; 19 - massifs: 1 - Chindagatuy, 2 - Orochagan, 3 - Akalakhin, 4 - Tekekundey, 5 - Kungurdjalin, 6 - Kalguty.

Inset: Altai accretion-collision system [Vladimirov et al., 2003, 2008]. 1 - Neoproterozoic - Early Paleozoic structural-substance complexes of the Siberian and Kazakhstan paleocontinents; 2 - Altai-Mongolian microcontinent; 3 - Ore-Altai island-arc terrane, 4 - Kalba-Narym turbidite terrane, 5 - Charsky oceanic terrane; 6 - Cenozoic sediments, 7 - granitoid batolites in the age range from Carboniferous to Early Jurassic inclusively; 8 - reliable (a) and assumed (б) faults; 9 - Kalguta Mo-W OMS.

дена на рисунке 6. Здесь отчетливо виден дискордантный характер онгонитовых даек по отношению к простиранию Иртышской сдвиговой зоны (ИСЗ) и Калба-Нарымского гранитоидного батолита, что, вероятнее всего, связано с кардинальной перестройкой АКС, синорогеническим коллапсом и постколлизионным растяжением континентальной литосферы. Следует подчеркнуть, что НовоАхмировский (Уланский) шток, расположенный в Иртышской сдвиговой зоне, не подвержен огнейсованию [Dovgal et al., 1995]. Эти геологические наблюдения имеют принципиальное значение, так как фиксируют инверсию геодинамического режима AKC. U/Pb изотопные датировки по цирконам позволили установить, что в эволюции КалбаНарымского батолита существует, по крайней меpe, три интрузивных ритма крупномасштабного гранитоидного магматизма (от раннего к позднемy): 1) раннекалбинский гранодиорит-гранитный, $295 \pm 1$ млн лет, 2) позднекалбинский гранит-лейко-

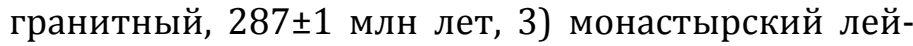
когранитный, $284 \pm 2$ млн лет. ${ }^{40} \mathrm{Ar} /{ }^{39} \mathrm{Ar}$ изотопные датировки по слюдам из тех же гранитоидов растягиваются в диапазоне от возраста формирования

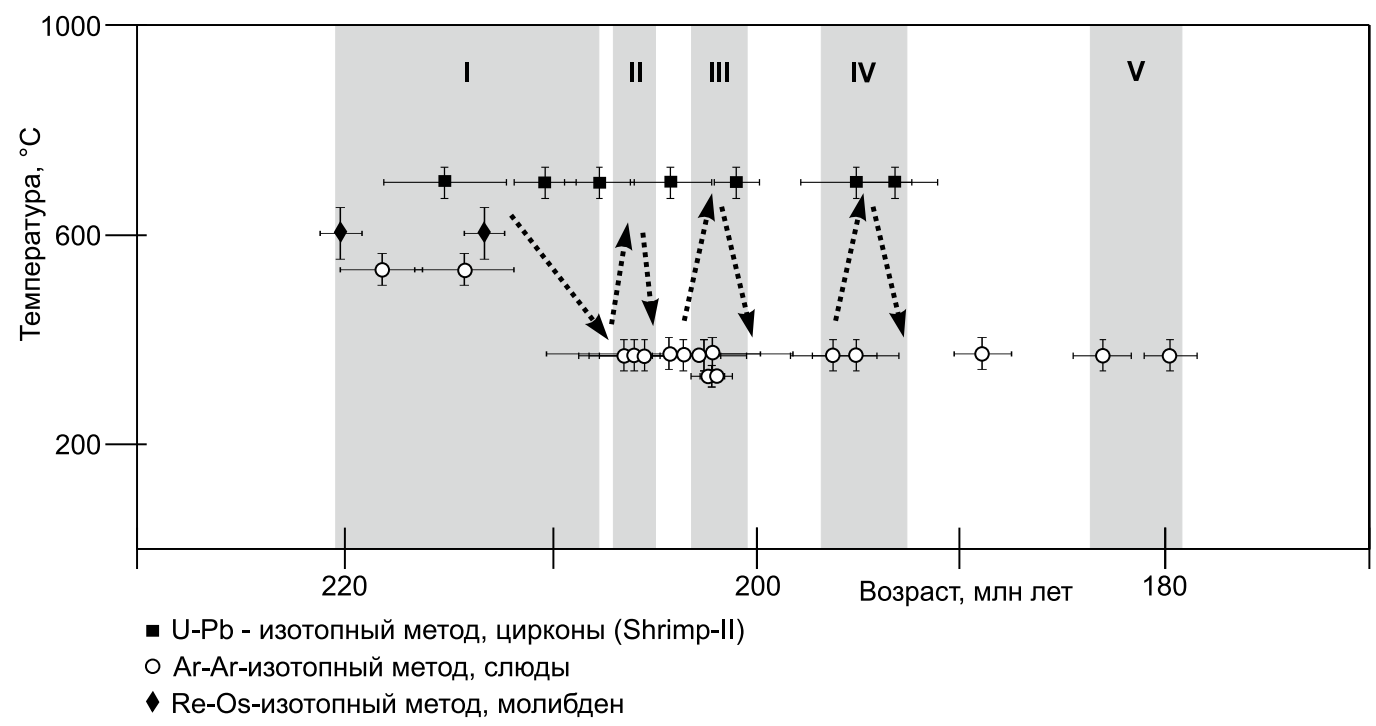

Рис. 4. Мультисистемная и мультиминеральная термохронограмма, отражающая температуру и возраст закрытия радиогенных систем в минералах Калгутинской РМС.

Fig. 4. Multi-system and multi-mineral thermochronology diagram, reflecting the temperature and age of the closure of radiogenic systems in the minerals of the Kalguta OMS. 
N.G. Murzintsev et al.: Thermochronology and mathematical modeling of the formation dynamics...

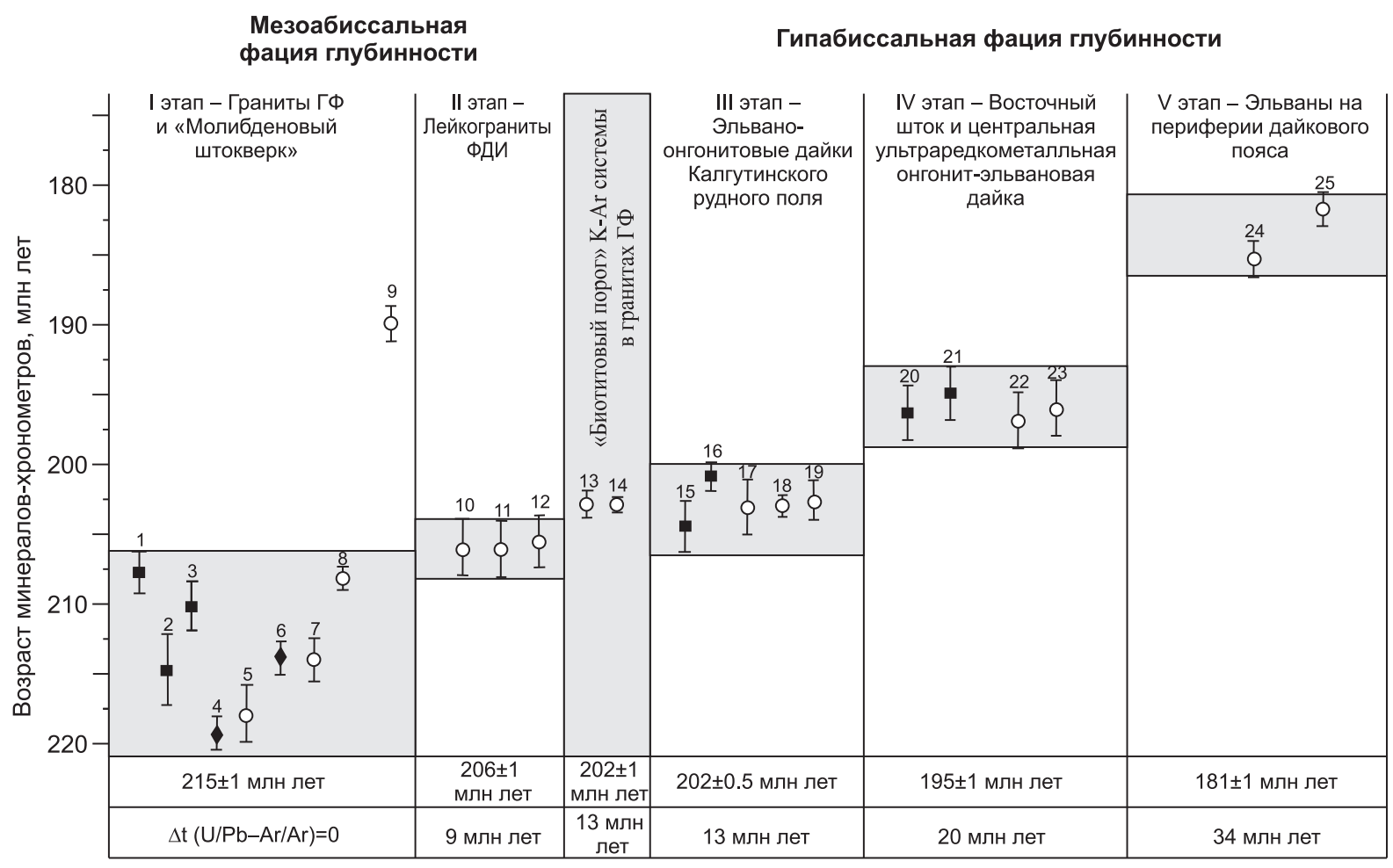

Возраст геологических объектов и рудно-магматических событий, млн лет

- U-Pb-изотопный метод, цирконы (Shrimp-II) Ar-Ar-изотопный метод, слюды $\quad$ Re-Os-изотопный метод, молибден

Рис. 5. Главные возрастные рубежи формирования Калгутинской РМС. Номера датировок на схеме соответствуют порядковым номерам в таблице 2.

Fig. 5. The main age boundaries of formation of the Kalguta OMS. The dating numbers in the diagram correspond to the sequence numbers in Table 2.

соответствующих комплексов, определенного с помощью $\mathrm{U} / \mathrm{Pb}$ метода по циркону, до значительно более молодых величин - порядка 270-267 млн лет [Kotler et al., 2015; Travin, 2016; Travin et al., 2016; Khromykh et al., 2016].

Время реактивации ИСЗ как глубинного литосферного разлома, разделяющего Горно-Алтайскую и Рудно-Алтайскую петрографические провинции, определяется позднекаменноугольными $\mathrm{U} / \mathrm{Pb}$ изотопными датировками $(314 \pm 3-313 \pm 1$ млн лет), которые коррелируются с ${ }^{40} \mathrm{Ar} /{ }^{39} \mathrm{Ar}$ возрастом амфибола из синкинематических габброидов Суровского массива [Khromykh et al., 2016] и биотита из гранитогнейсов Чечекской метаморфической структуры [Savinsky, Vladimirov, 2015; Travin et al., 2016]. Время завершения активности («замерзания») ИСЗ фиксируется по ${ }^{40} \mathrm{Ar} /{ }^{39} \mathrm{Ar}$ возрасту слюд из онгонитовых и лампрофировых даек миролюбовского комплекса [Khromykh et al., 2014, 2018a, 2018b] (T=272 2 млн лет) и литий-фтористых гранитов Ново-Ахмировского (Уланского) интрузивного штока [Annikova et al., 2019] (272 \pm 2 млн лет). Поскольку те и другие не подвержены деформациям и огнейсованию, следовательно, отражают син- орогенический коллапс коллизионного орогена и прекращение деформаций ИСЗ. Подчеркнем, что на финальный характер онгонитов и литий-фтористых гранитов, венчающих магматическую колонну в Калба-Нарымской зоне Рудного Алтая, уже давно обратили внимание В.Н. Довгаль и В.И. Маслов [Maslov et al., 1994; Dovgal et al., 1995], в статьях которых были приведены первые результаты $\mathrm{Rb}-\mathrm{Sr}$ изохронного датирования: $\mathrm{T}=272 \pm 4$ млн лет, $\left({ }^{87} \mathrm{Sr} /{ }^{86} \mathrm{Sr}\right)_{0}=0.707 \pm 7$ млн лет, $\left({ }^{87} \mathrm{Sr} /{ }^{86} \mathrm{Sr}\right)_{0}=0.735 \pm 40$, СКВО=0.97 (Ново-Ахмировский шток).

Ново-Ахмировский шток литий-фтористых гранитов приурочен к северо-западному флангу Чечекской метаморфогенной структуры, расположенной в пределах ИСЗ, и непосредственно примыкает к Калба-Нарымской структурно-формационной зоне (рис. 6). В строении Чечекской структуры участвуют гранитогнейсы, по существу, представляющие собой мигматизированную кровлю Суровского габброидного массива. Установлено, что дифференцированные габброиды Суровского массива и мигматит-граниты Чечекской кровли были сформированы в позднем палеозое (315-312 млн лет, $\mathrm{U} / \mathrm{Pb},{ }^{40} \mathrm{Ar} /{ }^{39} \mathrm{Ar}$ - изотопное датирование), а затем 


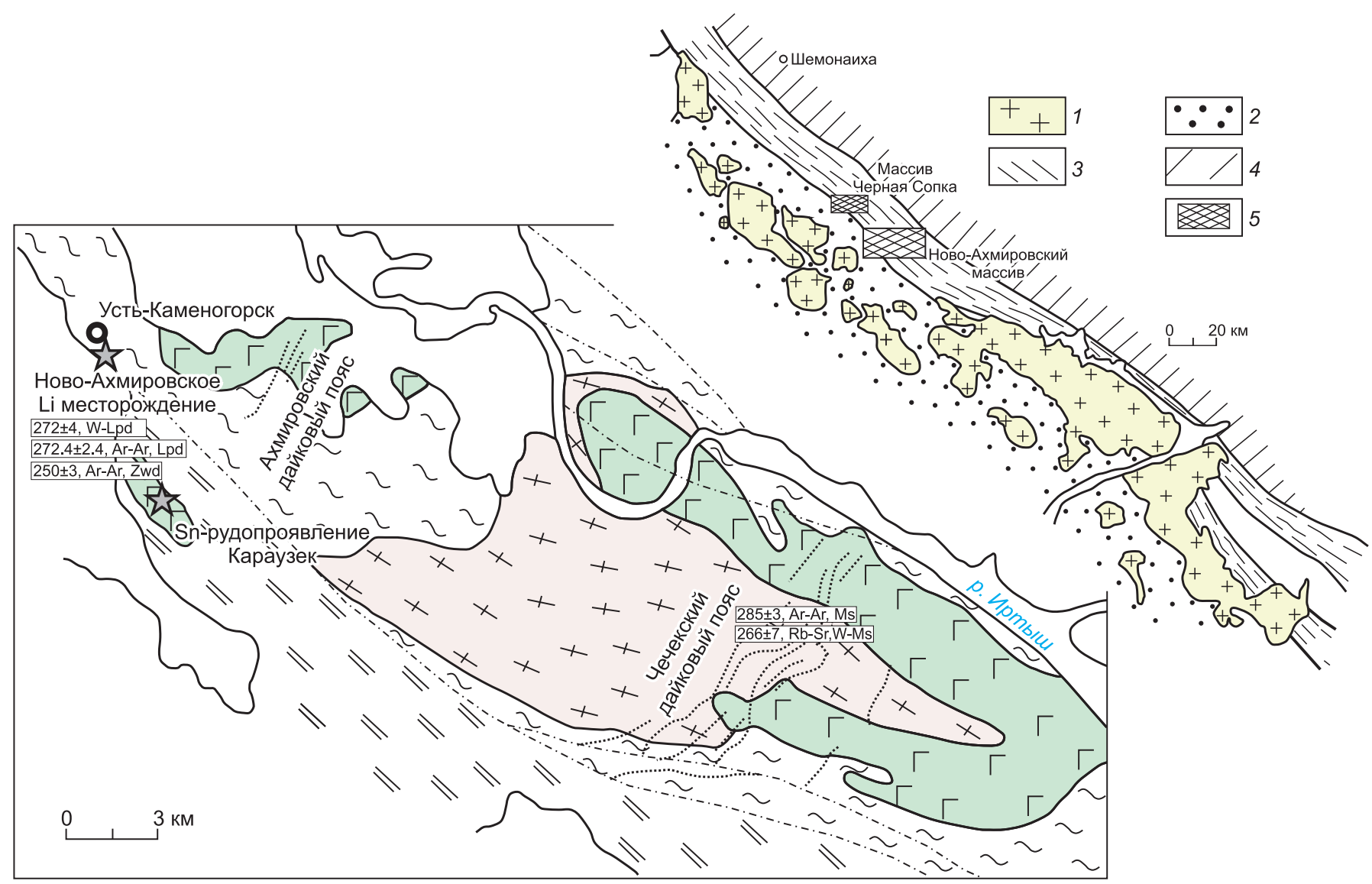

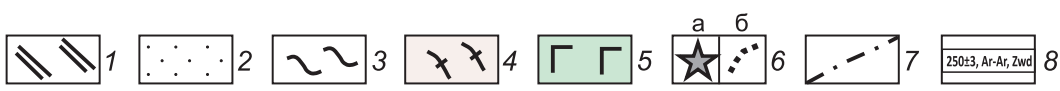

Рис. 6. Структурно-геологическая схема размещения онгонитов и литий-фтористых гранитов в центральной части Калба-Нарымской структурно-формационной зоны, Восточный Казахстан. Составлена В.И. Масловым и М.С. Козловым [Dovgal et al., 1995; Annikova et al., 2019].

1 - алевролиты и песчаники с линзами известняков и сланцев живетского яруса; 2 - песчаники, алевролиты, сланцы, известняки эйфельского яруса; 3 - гнейсы, амфиболиты, кристаллические сланцы Иртышской зоны смятия, нерасчлененные; 4 - гнейсогранодиориты и гнейсограниты Чечекского купола $\left(\mathrm{C}_{3}\right) ; 5$ - дифференцированные габброиды Суровского массива( $\left.\mathrm{C}_{3}\right) ; 6$ - топазовые циннвальдит-лепидолитовые граниты, $\mathrm{P}_{2}$; $6 б$ - онгонитовые дайки, $\mathrm{P}_{2}$; 7 - дизъюнктивные нарушения; 8 - результаты изотопного датирования (см. табл. 1).

На врезке: геологическая схема Калба-Нарымского гранитоидного батолита с вынесенным контуром полигона исследований. 1 - позднепалеозойские гранитоиды Калба-Нарымского батолита, нерасчлененные; 2 - девон-каменноугольные-осадочные отложения Калба-Нарымской зоны, нерасчлененные; 3 - Иртышская сдвиговая зона; 4 - Рудно-Алтайская структурно-формационная зона; 5 - полигон исследований.

Fig. 6. Structural-geological scheme the locations of ongonites and lithium-fluoride granites in the central part of the KalbaNarym structural-formation zone, East Kazakhstan. Compiled by V.I. Maslov and M.S. Kozlov [Dovgal et al., 1995; Annikova et al., 2019].

1 - siltstones and sandstones with lenses of limestone and shale of the Givetian stage; 2 - sandstones, siltstones, shales and limestones of the Eiffel stage; 3 - gneiss, amphibolites, crystalline schists of the Irtysh shear zone, undifferentiated; 4 - gneiss granodiorites and gneiss granites of the Chechek dome, $\mathrm{C}_{3} ; 5$ - differentiated gabbroids of the Surovsky massif, $\mathrm{C}_{3} ; 6 \mathrm{a}-$ topaz zinnwaldite-lepidolite granites, $\mathrm{P}_{2}$; $6 б$ - ongonite dykes, $P_{2} ; 7$ - faults; 8 - isotope ages (see Table 1).

Inset: Geologic scheme of the Kalba-Narym granitoid batholith and the study area (contoured). 1 - Late Paleozoic granitoids of the KalbaNarym batholith, undifferentiated; 2 - Devon-Carboniferous-sedimentary deposits of the Kalba-Narym zone, undifferentiated; 3 - Irtysh shear zone; 4 - Rudny Altai structural-formational zone; 5 - study area.

вошли в состав уже консолидированной метаморфической структуры и были экспонированы на верхние уровни земной коры (от 15-20 до 5-7 км). Во внешнем обрамлении Суровского массива с юго- запада на северо-восток (рис. 6) залегают углистые алевролиты и песчаники такырской свиты $\left(\mathrm{D}_{3}-\mathrm{C}_{1}\right)$, которые отделены от габброидов разрывными нарушениями. В северо-западном направлении эти 
N.G. Murzintsev et al.: Thermochronology and mathematical modeling of the formation dynamics...

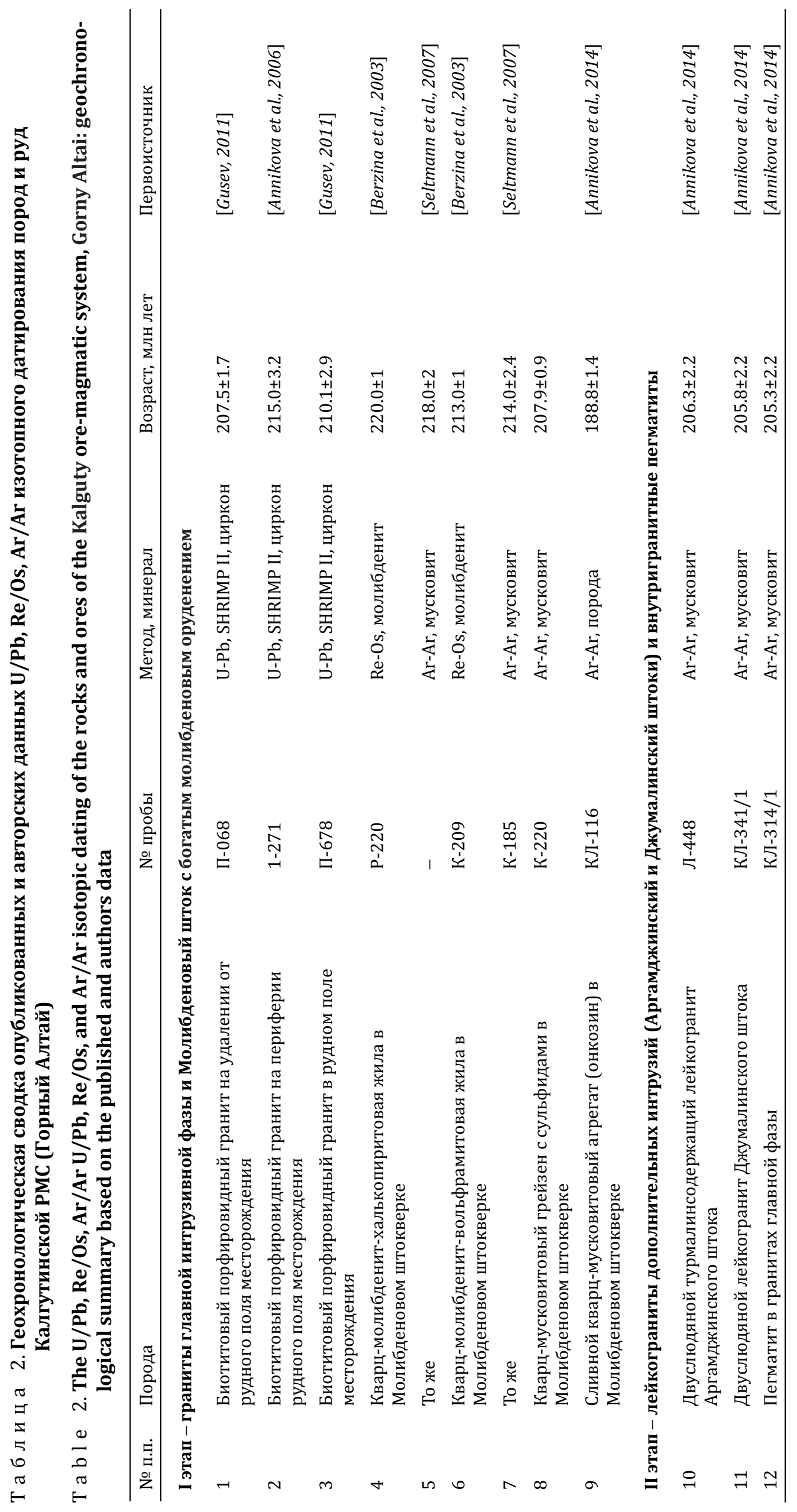




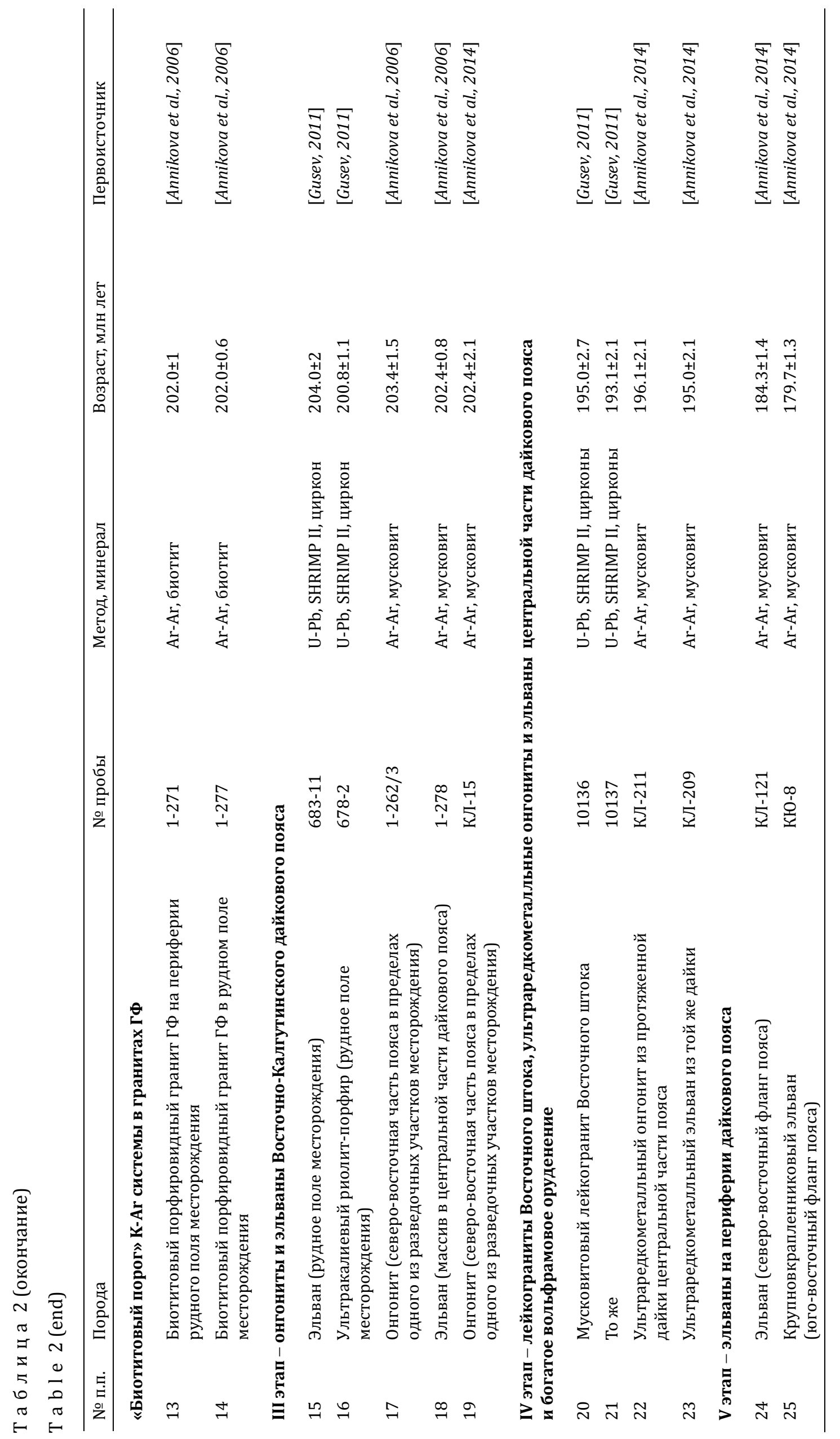




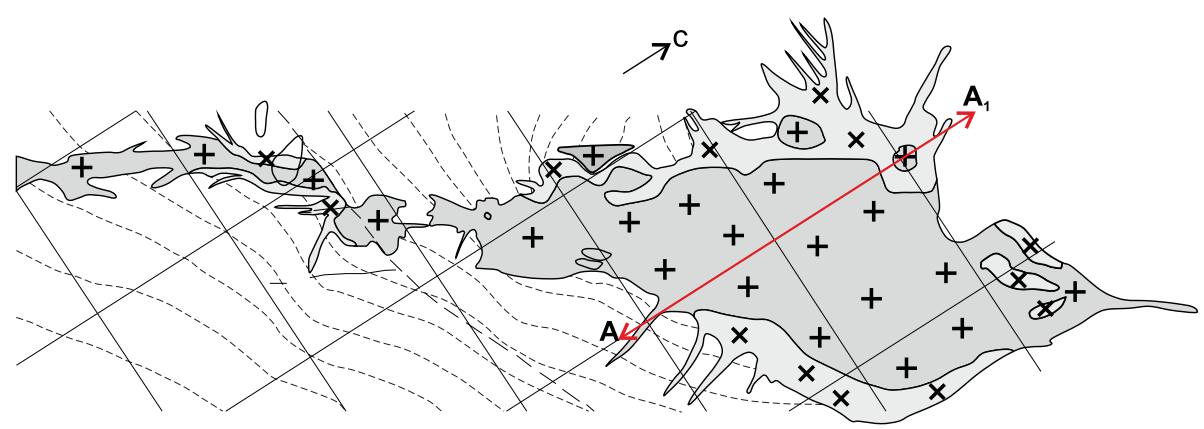

A

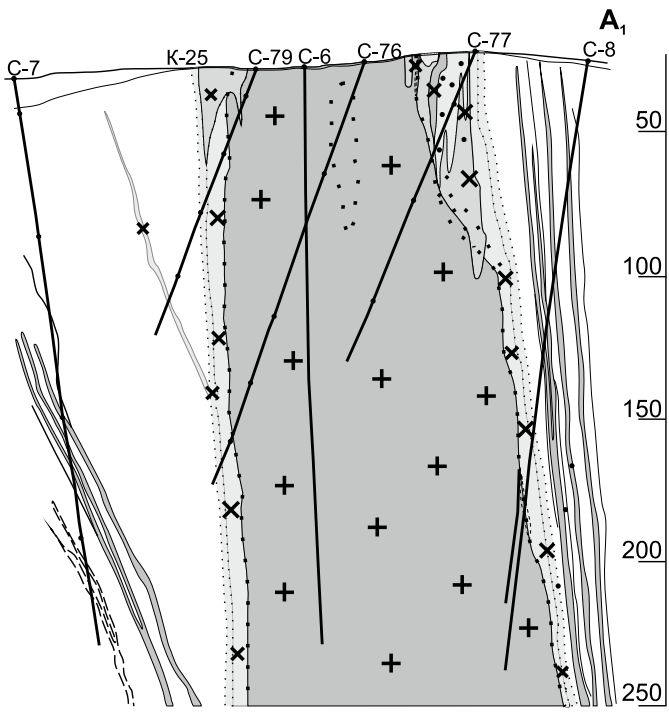

Рис. 7. Геологическая схема и глубинная морфология Ново-Ахмировского интрузивного штока. Составлена по данным крупномасштабного картирования и разведочного бурения [Maslov et al., 1994; Annikova et al., 2019 ].

1 - среднезернистые, часто порфировидные топаз-циннвальдитовые граниты главной интрузивной фазы (для структур характерны «горошковидные» выделения кварца и призматические кристаллы калиевого полевого шпата); 2 - мелкозернистые топаз-циннвальдитовые гранит-лейкограниты эндоконтактовой фации (подвержены неравномерной площадной грейзенизации, характерны аплит-пегматиты с резкими или постепенными переходами в граниты).

Fig. 7. Geological scheme and deep morphology of the Novo-Akhmirov intrusive stock. Based on the large-scale maps and exploration drilling data [Maslov et al., 1994; Annikova et al., 2019].

1 - medium-grained, often porphyritic opaz-zinnwaldite granites of the main intrusive phase ( typical structures are 'pea-shaped' quartz and prismatic crystals of potassic feldspar); 2 - fine-grained topaz-zinnwaldite granite-leucogranites of endocontact facies (subject to uneven areal greysening; aplite-pegmatites with sharp or gradual transitions to granite are typical).

породы сменяются зелеными сланцами ИСЗ [Savinsky, Vladimirov, 2015; Travin et al., 2016; Savinsky, 2017].

Геологическая схема современных выходов литий-фтористых гранитов и геологический разрез, полученный по разведочным скважинам, представлены на рисунке 7 [Annikova et al., 2019]. Интрузив перекрыт рыхлыми отложениями, при вскрытии канавами выявлена грубая зональность: центральная часть сложена среднезернистыми топазциннвальдитовыми гранитами с фациальными переходами в порфировидные разности с более тонкозернистым матриксом, для последних характерно обилие пегматоидных и аплитовидных жил, в том числе пересекающих грейзенизированные роговики. По данным геофизических работ и бурения сетки скважин [Maslov et al., 1994], эти граниты без видимого изменения структурно-текстурных особенностей были прослежены до глубины 324-374 м, что позволило интерпретировать глубинную морфологию интрузивного тела как трубообразную апофизу от глубинной магматической камеры [Maslov, 1994; Dovgal et al., 1995; Dyach$k o v, 2012]$. Кровля магматической камеры была зафиксирована гравиразведкой на глубине 1.5 км, что совпадает с геолого-геофизическими разрезами и расположением кровли отдельных гранитоидных массивов в центральной части Калба-Нарымского батолита [Shcherba et al., 1984].

Топаз-циннвальдитовые граниты, слагающие главную интрузивную фазу Ново-Ахмировского штока, - это светло-серые, кремово-серые породы 


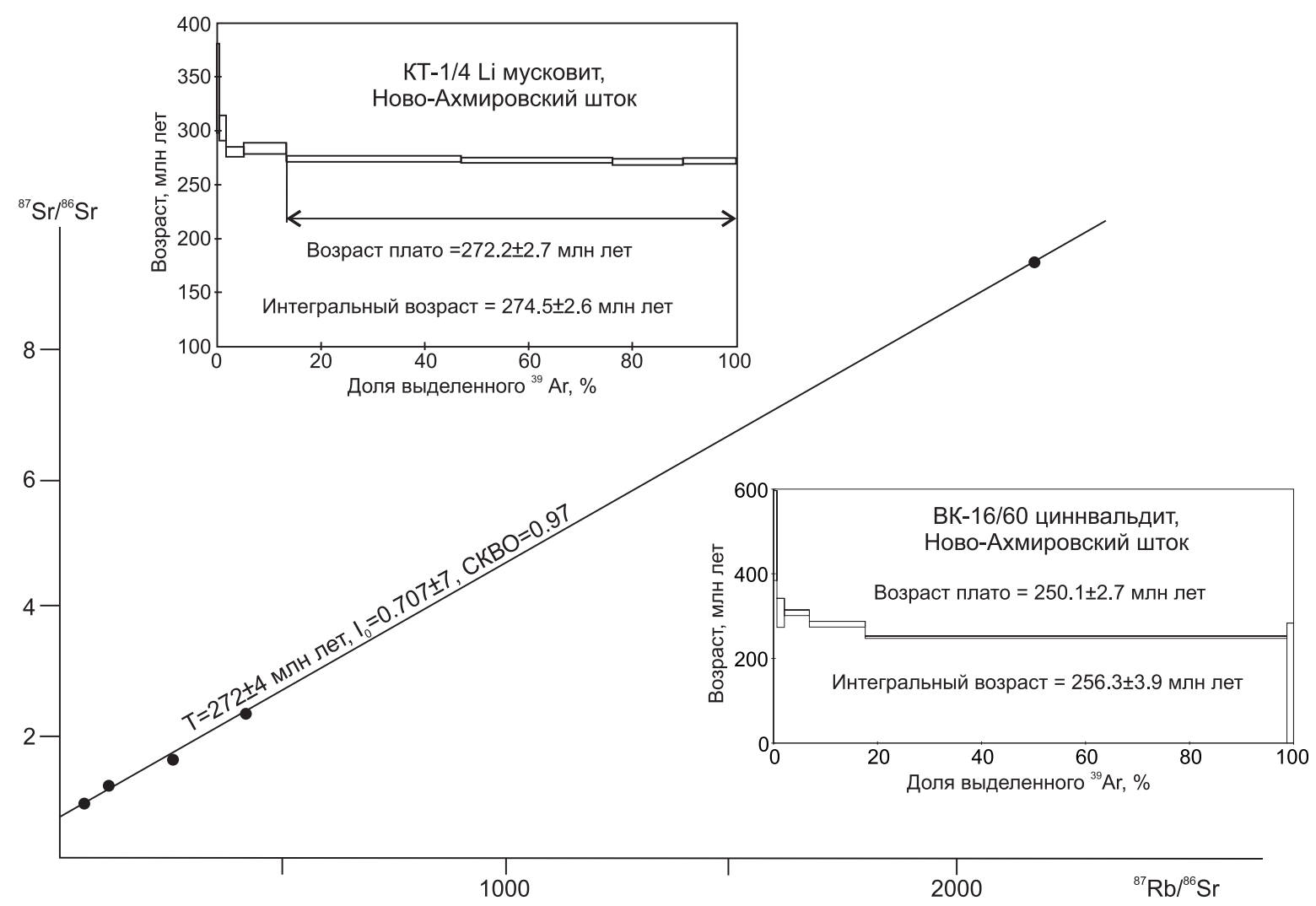

Рис. 8. Rb-Sr изохронная диаграмма (вал - слюды) и ${ }^{40} \mathrm{Ar} /{ }^{39} \mathrm{Ar}$ возрастные спектры (литиевый мусковит и циннвальдит) для литий-фтористых гранитов Ново-Ахмировского интрузивного штока [Dovgal et al., 1995; Khromykh et al., 2014; Annikova et al., 2019].

Fig. 8. $\mathrm{Rb} / \mathrm{Sr}$ isochron diagram (whole rock - mica) and ${ }^{40} \mathrm{Ar} /{ }^{39} \mathrm{Ar}$ age spectra (lithium muscovite and zinnwaldite) for lithium-fluoric granites of the Novo-Akhmirov intrusive stock [Dovgal et al., 1995; Khromykh et al., 2014; Annikova et al., 2019].

с массивной текстурой и равномерно-зернистой до слабопорфировидной структурой, сложенные горошковидным кварцем (30-40 \%), альбитом (25$40 \%)$, микроклином (15-35 \%), литиевой слюдой, варьирующейся по составу от циннвальдита до лепидолита (до $10 \%$ ), и топазом (до 5 \%). По геохимическим особенностям [Annikova et al., 2019] они обнаруживают значительное сходство со средними составами литий-фтористой фации плюмазитовых редкометалльных лейкогранитов [Tauson, 1977]. В топаз-циннвальдитовых гранитах Ново-Ахмировского интрузивного штока диагностирован широкий набор акцессорных минеральных фаз (в порядке уменьшения их распространенности): прозрачный топаз, голубоватый апатит, розовый полупрозрачный гранат, касситерит, танталит-колумбит, пирит, арсенопирит, сфалерит, галенит, халькопирит, циркон, полупрозрачный зеленовато-бурый турмалин, ильменит, рутил, сфен, магнетит, фосфаты РЗЭ (ксенотим, броккит). Более детальная минералого-петрографическая и геохимическая характеристика литий-фтористых гранитов Ново-Ах- мировского штока приведена в статье [Annikova et al., 2019].

В рамках предпринятого в настоящей статье исследования была проведена ревизия геохронологических возрастов на основе ${ }^{40} \mathrm{Ar} /{ }^{39} \mathrm{Ar}$ датирования «белых» слюд из литий-фтористых гранитов НовоАхмировского штока. Для ${ }^{40} \mathrm{Ar} /{ }^{39} \mathrm{Ar}$ изотопных исследований было проведено выделение мономинеральных фракций Li-мусковита и циннвальдита из образцов наиболее свежих гранитов центральной части Ново-Ахмировского штока (обр. КТ-1/4, обр. ВК-16-60). Полученные даты подтвердили предшествующие $\mathrm{Rb} / \mathrm{Sr}$ оценки и показаны на одном рисунке с $\mathrm{Rb} / \mathrm{Sr}$ изохронной диаграммой (рис. 8). Обращает на себя внимание то, что $\mathrm{Rb} / \mathrm{Sr}$ (вал - слюды) и ${ }^{40} \mathrm{Ar} /{ }^{39} \mathrm{Ar}$ изотопные даты по $\mathrm{Li}$ - мусковитам совпадают в пределах аналитической погрешности $(272 \pm 2$ млн лет), в то время как циннвальдит не дает устойчивого плато в возрастном ${ }^{40} \mathrm{Ar} /{ }^{39} \mathrm{Ar}$ спектре и, вероятнее всего, фиксирует значительно более поздние ( $\geq 20$ млн лет) термальные события в Иртышской сдвиговой зоне (см. рис. 8). 


\section{4. МЕТОДОЛОГИЯ ЧИСЛЕННОГО МОДЕЛИРОВАНИЯ ТЕРМИЧЕСКИХ ИСТОРИЙ РУДНО-МАГМАТИЧЕСКИХ СИСТЕМ}

В общем случае формула расчета температуры закрытия изотопной системы, предложенная М. Додсоном [Dodson, 1973], не имеет аналитического решения. Это актуально и для случаев термических историй гранитоидных батолитов, а также связанных с ними редкометалльных РМС, часто имеющих длительную, многостадийную термическую историю. С учетом сказанного при интерпретации данных мультисистемного и мультиминерального изотопного датирования нами, с одной стороны, проводилось численное моделирование динамики остывания и кристаллизации гранитоидного расплава, с другой - для полученных модельных термических историй в пределах гранитоидного массива и вмещающих его пород проводилось решение уравнения диффузии дочернего изотопа ( ${ }^{40} \mathrm{Ar}$ радиогенного) в минералах-геотермохронометрах. При расчетах использовались кинетические параметры, полученные для основных минералов-геотермохронометров в лабораторных гидротермальных экспериментах (сводка [Hodges, 2003]). Суть предложенного подхода состоит в подборе методом решения обратной задачи сценариев эволюции гранитоидных батолитов, при которых расчетные времена закрытия изотопных систем согласуются с экспериментальными результатами мультисистемного и мультиминерального датирования.

Решение уравнения теплопроводности проводилось численным методом, основанным на центральносимметричной разностной схеме. При выборе начальных условий моделирования учитывались: 1) наблюдаемый диапазон датировок одной изотопной системы в минеральных зернах одного вида, зависящий от положения точки отбора в пределах гранитоидного массива (например, центр - край, кровля - нижняя часть или же в пределах современного эрозионного среза), а также от принадлежности изученных образцов к различным магматическим комплексам, фазам магматизма; 2) диапазон значений датировок, полученных различными изотопными методами по минералам одной пробы; 3) наличие поздних процессов по отношению к магматической камере, этапы формирования которой могут быть разделены во времени на десятки миллионов лет. Моделируя те или иные конфигурации и последовательность геологических событий, в том числе наложенных, можно подобрать термические истории, которые будут удовлетворять реальным датировкам с достаточно большой степенью достоверности. Таким образом становится возможным подтвердить или опровергнуть тот или иной вариант геологического сценария.

\section{1 АЛГОРИТМ МАТЕМАТИЧЕСКОГО МОДЕЛИРОВАНИЯ}

Процесс кристаллизации и остывания консолидированного блока описывается уравнением диффузии тепла (закон Фика) при учете стандартного теплового потока, который закладывается первоначальным геотермальным градиентом у земной поверхности и распределением тепловых источников, обусловленных радиоактивным распадом делящихся элементов в земной коре. В силу вязкости гранитной магмы, в первом приближении конвективный перенос тепла не учитываем, но при этом стоит учесть скрытую теплоту кристаллизации. Тогда в общем виде это уравнение запишется как:

$$
\frac{d T(x, y, t)}{d t}=\frac{1}{C(x, y) \rho(x, y)}\left(\nabla(k(x, y) \nabla \mathrm{T}(x, y, t))+P_{\text {рад }}(t)+H \rho \frac{d h}{d t}\right),
$$

где $H$ - удельная теплота кристаллизации (300-420 кДж/кг, прямо пропорциональная зависимость от мафичности расплава [Vigneresse, 2015]), $\rho$ - плотность горных пород, $C$ - теплоемкость, $T$ - температура, $k$ - теплопроводность, $P_{p a \partial}(\mathrm{t})$ - тепловая мощность распределенных источников тепла от делящихся элементов, $\frac{d h}{d t}$ - приведенная скорость кристаллизации расплава, $\mathrm{x}, \mathrm{y}-$ координата горизонтали и глубина, соответственно.

Скорость кристаллизации расплава находим из соображений, что в момент кристаллизации температура в данной точке не меняется и равна температуре солидуса, то есть необходимо решить стационарное уравнение теплопроводности относительно $\frac{d h}{d t}$ :

$$
\nabla(k(x, y) \nabla \mathrm{T}(x, y, t))+P_{\text {рад }}(y, t)+H \rho \frac{d h}{d t}=0 .
$$

Тепловую мощность делящихся элементов можно оценить исходя из активности чистого вещества, энергии распада и содержания в породе:

$$
P_{\text {рад }}(y, t)=\sum_{i} A_{i} E_{i} c_{i}(y, t) .
$$


Температурное поле во вмещающих породах должно соответствовать стационарному решению данного уравнения теплопроводности с учетом стандартного геотермического градиента температур у поверхности и средней температуры поверхности планеты, т. е:

$$
\begin{aligned}
& \frac{1}{C(x, y) \rho(x, y)}\left(\nabla(k(x, y) \nabla \mathrm{T}(x, y, t))+P_{\text {рад }}(y, t)\right)=0 \\
& \left.\frac{\partial T}{\partial y}\right|_{y=0}=30^{\circ} \mathrm{C} / \text { км } \quad T(y=0)=17^{\circ} \mathrm{C} .
\end{aligned}
$$

Решением данной системы является следующая зависимость [Ehlers, 2005; Roger et al., 2011; Polyansky et al., 2011]:

$$
T(y)=T_{s}+\left.\frac{\partial T}{\partial y}\right|_{y=0} y-\frac{P_{\mathrm{paz}}(y, t) y^{2}}{2 k} .
$$

Зависимость мощности радиоактивного тепла от глубины можем определить следующим образом: $P_{\text {рад }}(y)=P_{0} e^{-\frac{y}{y_{0}}}$, где $P_{0}$ - объемное содержание тепловой мощности делящихся элементов на земной поверхности, уо - характерная глубина распространения делящихся элементов (5-15 км [Ehlers, 2005; Roger et al., 2011]).

В качестве граничных условий на поверхности может послужить закон Стефана-Больцмана. На боковых и нижней границах расчетной области температура постоянна и отвечает геотермическому стационарному решению уравнения теплопроводности. То есть граничные условия примут вид:

$$
\begin{aligned}
& \frac{\partial T}{\partial t}=\frac{1}{C(x, y=0) \rho(x, y=0)}\left(\nabla(k(x, y=0) \nabla \mathrm{T}(x, y=0, t))+P_{\text {рад }}(t)+\frac{d I}{d y}\right), \\
& \left.\frac{\partial T}{\partial t}\right|_{x=0}=\left.0 \quad \frac{\partial T}{\partial t}\right|_{x=L}=\left.0 \quad \frac{\partial T}{\partial t}\right|_{y=H}=0,
\end{aligned}
$$

где I - интегральная светимость, определяемая законом Стефана-Больцмана (уносимый интегральный тепловой поток).

Свойства пород, такие как плотность, теплопроводность и теплоемкость, можно определить как суперпозицию данных свойств слагающих минералов в соответствии с их содержанием в породе. То есть

$$
\begin{aligned}
& \rho=\sum_{i} \rho_{i} c_{i} \\
& C=\sum_{i}^{i} C_{i} c_{i} \\
& k=\sum_{i}^{i} k_{i} c_{i},
\end{aligned}
$$

где $\rho$ - плотность, $C$ - теплоемкость и $k$ - теплопроводность горной породы, $c_{i}-$ содержание і-го минерала в породе, а $\rho_{i}, C_{i}$ и $k_{i}$ - его плотность, теплоемкость и теплопроводность.

Температура солидуса водонасыщенной гаплогранитной смеси, как указывается в литературе, зависит от давления следующим образом: $730{ }^{\circ} \mathrm{C}$ при 0.7 кбар, $680{ }^{\circ} \mathrm{C}$ при 2 кбар, $660{ }^{\circ} \mathrm{C}$ при 3 кбар и $645^{\circ} \mathrm{C}$ при 5 кбар [Johannes, Holtz, 1996]. Таким образом, если предположить, что с некоторого значения давления эта величина выходит на стационар (это не совсем так, но для используемого в модели диапазона давлений это допущение возможно), то можно аппроксимировать ее экспоненциальной зависимостью на данном участке:

$$
T_{\text {sol }}(P)=A e^{-\gamma P}+T_{\text {sol_st }} .
$$

Варьируя $T_{\text {sol_st }}$ на каждой итерации методом наименьших квадратов, можно найти оптимальное значение стационарной температуры солидуса. Наименьшая погрешность аппроксимации находится в точке со значением $T_{\text {sol_st }}=638.6283{ }^{\circ} \mathrm{C}$ со следующими значениями оптимальных параметров аппроксимации: $A=141.0885^{\circ} \mathrm{C}, \gamma=0.6211$ кбар $^{-1}=6.211 \mathrm{MПа}^{-1}, T_{\text {sol_st }}=638.6283{ }^{\circ} \mathrm{C}$, среднеквадратичное отклонение для данной аппроксимации составило $0.4077^{\circ} \mathrm{C}$. Так как разработанный алгоритм не предполагает прямой геотермохимической дифференциации состава, было принято, что температура кристаллизации меняется от $T_{\text {sol }}(P)$ в начальный момент времени (соответствует гранитам главной фазы) до $T_{\text {sol_st }}$ в конечный момент (что соответствует позднему редкометалльно-рудному магматизму) пропорционально объему остаточного расплава: 
N.G. Murzintsev et al.: Thermochronology and mathematical modeling of the formation dynamics...

$$
T_{\text {sol }}=\frac{T_{\text {sol }}(P)-T_{\text {sol_st }}}{V_{0}} V+T_{\text {sol_st }},
$$

где $T_{s o l}$ - температура кристаллизации дифференцированного расплава, $V_{0}$ - объем начальной магматической камеры, $V$ - объем остаточного расплава. Таким образом, можно оценить длительность формирования и зональность гранитного тела, а также предположить источники вторичного магматизма для случая замкнутой системы, т. е. в данном случае рассматривается формирование на начальном этапе магматической камеры и последующая ее эволюция. Все последующие этапы магматизма происходят при ее тектонических нарушениях за счет дифференцированного в пределах камеры расплава.

Программный алгоритм был реализован на языке программирования MATLAB в одноименном пакете математических программ и опробован на ряде объектов, в числе которых Калгутинская и Ново-Ахмировская РМС.

\section{2. НАЧАЛЬНЫЕ И ГРАНИЧНЫЕ УСЛОВИЯ ДЛЯ МАТЕМАТИЧЕСКОГО МОДЕЛИРОВАНИЯ КАЛГУТИНСКОЙ РМС}

При численном моделировании термической истории формирования Калгутинской РМС были учтены физические свойства пород, представленные на рис. 9. Морфология и глубинное строение Калгутинской PMC представлены в виде системы: «верхняя магматическая камера (гранитоидный батолит) - подводящая ножка - глубинный гранитный слой)». Последний слой, вероятнее всего, был тесно взаимосвязан с магмообразующим субстратом. Возрастные рубежи формирования Калгутинской РМС отражены на

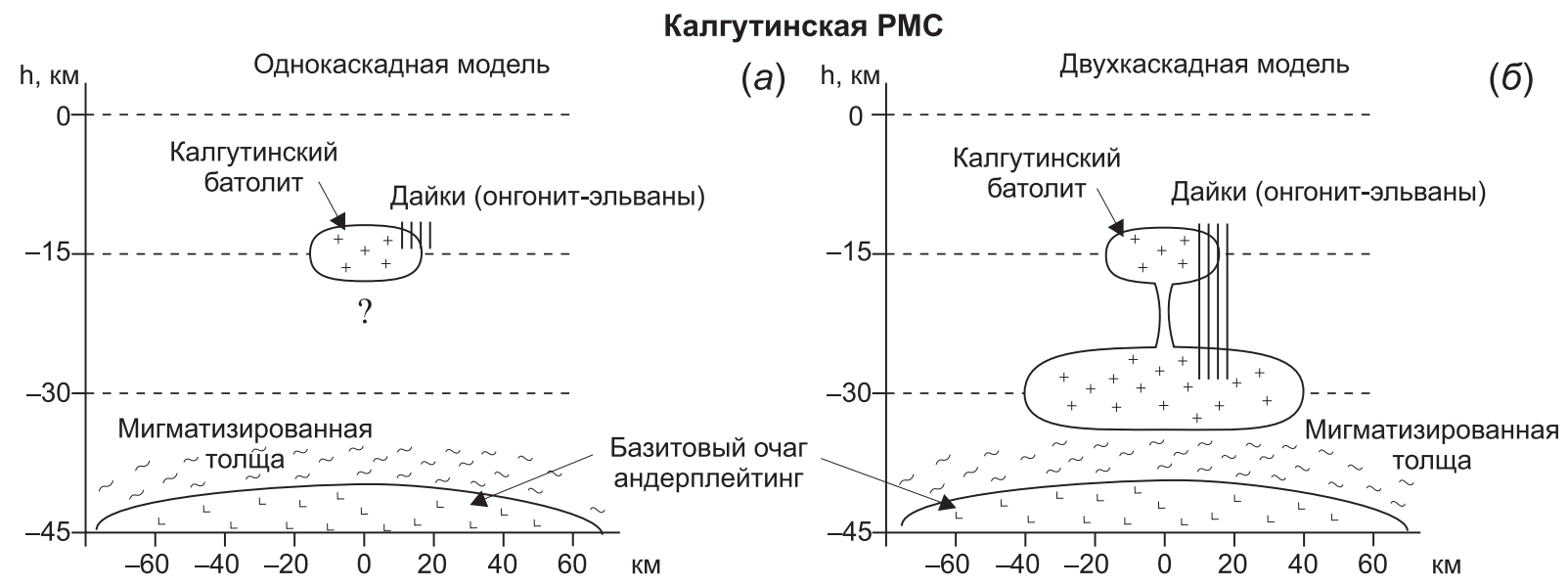

Ново-Ахмировская РМС

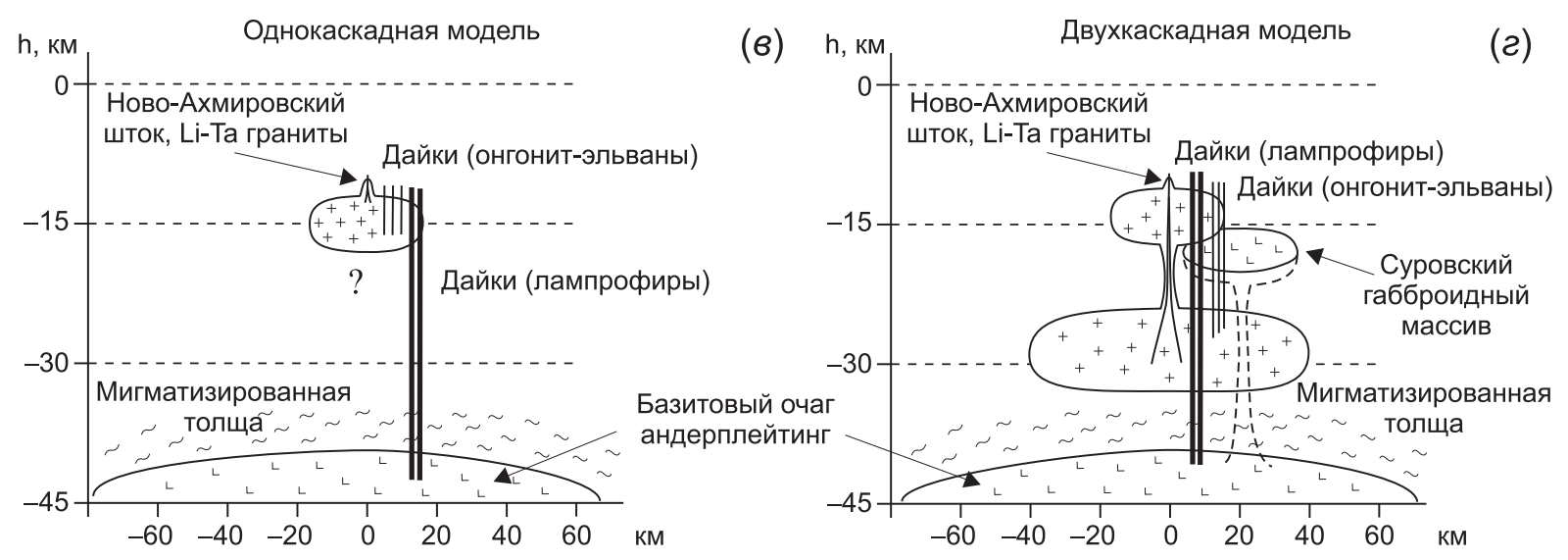

Рис. 9. Конфигурация РМС, принятых для численного моделирования термических историй алтайских редкометалльно-гранитных месторождений. Пояснения в тексте.

Fig. 9. Configurations of the ore-magmatic systems for the numerical modelling of the thermal history of the Altai rare-metal granite deposits. See explanations in the text. 
рисунке 9, при этом растяжение континентальной литосферы («биотитовый порог», «мгновенная декомпрессия») принято в алгоритме как механическое перемещение магматической колонны с глубинного на верхний уровень земной коры. В качестве протолита взяты граувакки горно-алтайской осадочновулканогенной серии раннепалеозойского возраста [Shokalsky et al., 2000; Kruk, 2015]. Нормативный минеральный состав граувакк горно-алтайской терригенной толщи: кварц - $16 \%$, плагиоклаз - 50 \%, ортоклаз - $6.3 \%$, диопсид - $1.4 \%$, гиперстен - $11.8 \%$, гематит - $9 \%$. Состав родоначальной магмы, очевидно, отвечал гранитам главной фазы (табл. 2). Усредненный минеральный нормативный состав гранитов главной фазы Калгутинского батолита: Qz - 30 \%, плагиоклаз - 35 \%, кпш - 35 \%. Температурный режим Калгутинской РМС оценен на основе Zr-термометра [Watson, Harrison, 1983; Boehnke et al., 2013]. Согласно проведенным расчетам [Vladimirov et al., 2018], наиболее высокотемпературными породами Калгутинской РМС являются биотитовые граниты первой фазы внедрения $\left(857-815{ }^{\circ} \mathrm{C}\right.$, средняя $-835{ }^{\circ} \mathrm{C}$ по трем анализам); лейкограниты второй фазы внедрения, согласно проведенной оценке, имеют относительно широкие вариации температур $-812-701{ }^{\circ} \mathrm{C}$ (средняя $-750{ }^{\circ} \mathrm{C}$ по четырем анализам); для онгонитов, относимых к третьей и четвертой фазам, получены самые низкие значения температур - 693-652 ${ }^{\circ} \mathrm{C}$ (средняя $-674{ }^{\circ} \mathrm{C}$ по пяти анализам). Эти данные согласуются с общим гомодромным трендом Калгутинской РМС, когда температуры падают от биотитовых гранитов через лейкограниты к онгонитам, что соответствует выделяемым интрузивным фазам. Учитывая вышесказанное, за температуру ликвидуса родоначальной гранитной магмы принято значение $\mathrm{T}=815{ }^{\circ} \mathrm{C}$. Температура солидуса остаточного гранитного расплава, в зависимости от глубины кристаллизации, принята в интервале $\mathrm{T}=600-630{ }^{\circ} \mathrm{C}$ на основе термобарогеохимического изучения расплавных включений в онгонитах и эльванах Восточно-Калгутинского дайкового пояca [Sokolova et al., 2011].

\section{3. НАЧАЛЬНЫЕ И ГРАНИЧНЫЕ УСЛОВИЯ ЧИСЛЕННОГО МОДЕЛИРОВАНИЯ ТЕРМИЧЕСКОЙ ИСТОРИИ Ново-АХмИРОвСКОЙ РМС (РУднЫЙ АЛТАЙ, РZ3)}

При моделировании термической истории формирования редкометалльных рудопроявлений КалбаНарымского гранитоидного батолита (Ново-Ахмировская РМС) были рассмотрены две модели: однокаскадная и двухкаскадная магматические колонны, заполненные гранитным расплавом. Состав гранитной магмы отвечал среднему составу главной фазы калбинского комплекса, средний приведенный состав которой составляет (\%) [Kotler et al., 2015]: кварц - 27.13, плагиоклаз - 38.3, ортоклаз - 25.71, корунд - 1.9, гиперстен - 2.07, рутил - 0.38, ильменит - 0.13, гематит - 3.91, апатит - 0.44, циркон - 0.04. Состав вмещающей рамы соответствовал среднему нормативному составу такырской свиты (\%): кварц - 33.12, плагиоклаз - 39, ортоклаз - 11.58, корунд - 1.69, гиперстен - 7.32, рутил - 0.61, ильменит - 0.21, гематит - 6.09, апатит - 0.37. Для данных составов были пересчитаны плотность, теплоемкость и теплопроводность слагающих пород. Для указанного выше среднего нормативного минерального состава родоначальной гранитной магмы оценка температуры ликвидуса составила $860-850{ }^{\circ} \mathrm{C}$. Температура солидуса расплава определялась в соответствии с давлением и степенью консолидации расплава, как указано выше в математической модели. По причине уникальности Ново-Ахмировского штока топаз-циннвальдитовых гранитов также предпринята попытка оценить химический состав кристаллизовавшихся пород и остаточного расплава. В силу крайне малых размеров Ново-Ахмировского штока Li-F гранитов и скрытого под ним гранитного массива (поперечный размер штока 300 м, а массива 5-20 км), остывание после кристаллизации должно было быть быстрым, поэтому за возраст внедрения массива можно принять ${ }^{40} \mathrm{Ar} /{ }^{39} \mathrm{Ar}$ датировку (272 млн лет) [Annikova et al., 2019].

\section{5. РЕЗУЛЬТАТЫ МАТЕМАТИЧЕСКОГО МОДЕЛИРОВАНИЯ}

\section{1. КАЛГУТИНСКАЯ РМС}

По геолого-геофизическим данным [Annikova et al., 2004, 2006; Potseluev et al., 2008; Vladimirov et al.,1997, 1998, 2019] массив представляет собой изометричное тело с поперечным размером 25 км, из которого на поверхности наблюдается овальный участок $10 \times 7$ км. Его окружает глубинная гравитационная аномалия с характерным размером в по- перечнике порядка 40 км. В качестве начального приближения была рассмотрена однокаскадная модель, в которой магматическая камера, согласно геофизическим данным, была аппроксимирована телом цилиндрической формы мощностью 6 км, диаметром 25 км, глубиной залегания 6 км с подводящим каналом «ножкой» диаметром 5 км и глубиной простирания на 9 км под подошву массива, расположенным соосно с массивом (рис. 9, a). В расчетах была прослежена эволюция магматического тела до 12 млн лет с момента внедрения. Ре- 
N.G. Murzintsev et al.: Thermochronology and mathematical modeling of the formation dynamics...

зультаты показывают, что кристаллизация остаточного расплава в данной системе происходит в первые миллионы лет. Таким образом, в данном приближении более поздний гранитоидный магматизм может быть объяснен лишь с привлечением дополнительных магматических очагов и/или андерплейтинга. С учетом сказанного было допущено предположение о наличии еще одной, связанной с существующей, глубинной магматической камеры и предложена двухкаскадная модель (рис. 9, б). Наблюдаемая верхняя камера в этом варианте представлена дискообразным гранитным телом (диаметр 25 км и мощность 6 км с глубиной залегания 6 км) с подводящим каналом в центре (диаметр 5 км и простирание от подошвы верхней камеры до кровли нижней). Подстилающая нижняя магматическая камера (диаметр 40 км и мощность 9.5 км с глубиной залегания 20 км) имеет поперечный размер, соответствующий Калгутинской вулканической мульде [Annikova et al., 2004, 2006; Vladimirov et al., 1997, 1998, 2019]. Поскольку по ${ }^{40} \mathrm{Ar} /{ }^{39} \mathrm{Ar}$ изотопным датировкам фиксируется тектонический этап поднятия Калгутинского батолита до глубин закрытия K-Ar изотопной системы в биотите, в модель необходимо добавить тектонический взброс всей магматической колонны и эрозию геоблока, то есть разгрузку кровли над магматической камерой (в данном случае - гранитоидным батолитом).

Численное моделирование предложенной двухкаскадной структуры показало (рис. 10), что расплав с момента внедрения эволюционирует 12 млн лет, после чего происходит взброс всей территории на 5 км (переход кровли верхнего массива через «биотитовый порог») и далее система продолжает эволюционировать еще порядка 5 млн лет. Таким образом, при геотермальном градиенте у поверхности $30{ }^{\circ} \mathrm{C} / к м$ и кларковом содержании основных делящихся элементов в нижней коре [Polyansky et al., 2011] через 12 млн лет остаточный расплав может сохраняться в подошве нижнего каскада на глубине от 25.5 км до подошвы нижнего каскада ( 30 \% от общего объема камер); после тектонического взброса остаточный расплав может сохраняться у подошвы нижнего каскада еще в течение 5 млн лет [Vladimirov et al., 2019].

\section{2. НОВО-АХМИРОВСКАЯ РМС}

При моделировании редкометалльных рудопроявлений Калба-Нарымской зоны (Ново-Ахмировский шток) в качестве источника образования рудных тел рассматривались остаточные расплавы, связанные с дифференциацией глубинного магматического очага гранитного состава. Требовалось оценить, с какой глубины поступил редкоме- талльно-гранитный расплав. По аналогии с Калгутинской РМС рассмотрено две модели (см. рис. 9, $a$, б).

Однокаскадная модель. При моделировании однокаскадной модели (см. рис. 9, в) исходная магматическая камера представлена в форме пластины мощностью 5 км и глубиной залегания 5 км, с подводящим каналом высотой 7 км. Она соответствует возрасту 300 млн лет, приблизительному времени появления «гранитного слоя» в нижней коре, продуцирующего внедрение в той или иной мере дифференцированных расплавов и формирование верхних камер, то есть Калба-Нарымского полихронного гранитоидного батолита на современном эрозионном срезе.

Результаты моделирования показывают, что при данной конфигурации магматического тела длительность жизни расплава в камере не превышает 1.6 млн лет. То есть источник расплава для «вторичного» магматизма на момент внедрения Ново-Ахмировского штока (возраст 272 млн лет) в данной модели отсутствует, а времена не согласовываются. В связи с этим, по аналогии с Калгутинской РМС, нами рассмотрена двухкаскадная модель магмо- и рудогенеза.

Двухкаскадная модель. В данной модели эволюция гранитной магмы происходит в двухуровневой магматической колонне, где составная камера на уровне промежуточных глубин соответствует гранитным массивам калбинского комплекса и нижняя камера соответствует источнику родоначального расплава (см. рис. 9, 2). При этом на момент времени, отстоящего от момента формирования нижнекорового «гранитного» слоя на 28 млн лет (272 млн лет, момент внедрения НовоАхмировского штока), в системе должен сохраняться остаточный расплав. Диаметр верхнего каскада принят равным 40 км, мощность - 5 км, глубина залегания 5 - км. Для нижнего каскада принят диаметр 80 км, мощность 9.5 км, глубина залегания -20 км.

Результаты численного моделирования (рис. 11) показывают, что подводящий канал консолидируется в первые 0.7 млн лет, а верхняя камера - через 1.5 млн лет. Таким образом, они не могут быть источниками дифференциата для Ново-Ахмировского штока топаз-циннвальдитовых гранитов. Через 28 млн лет остаточный расплав сохраняется только в нижней камере в виде линзовиднодискообразного тела с глубиной залегания кровли порядка 25 км. Таким образом, источником расплава для Ново-Ахмировского редкометалльногранитного штока мог послужить лишь остаточный расплав, внедрившийся из нижней глубинной камеры (при данной конфигурации с глубины более 26 км). 

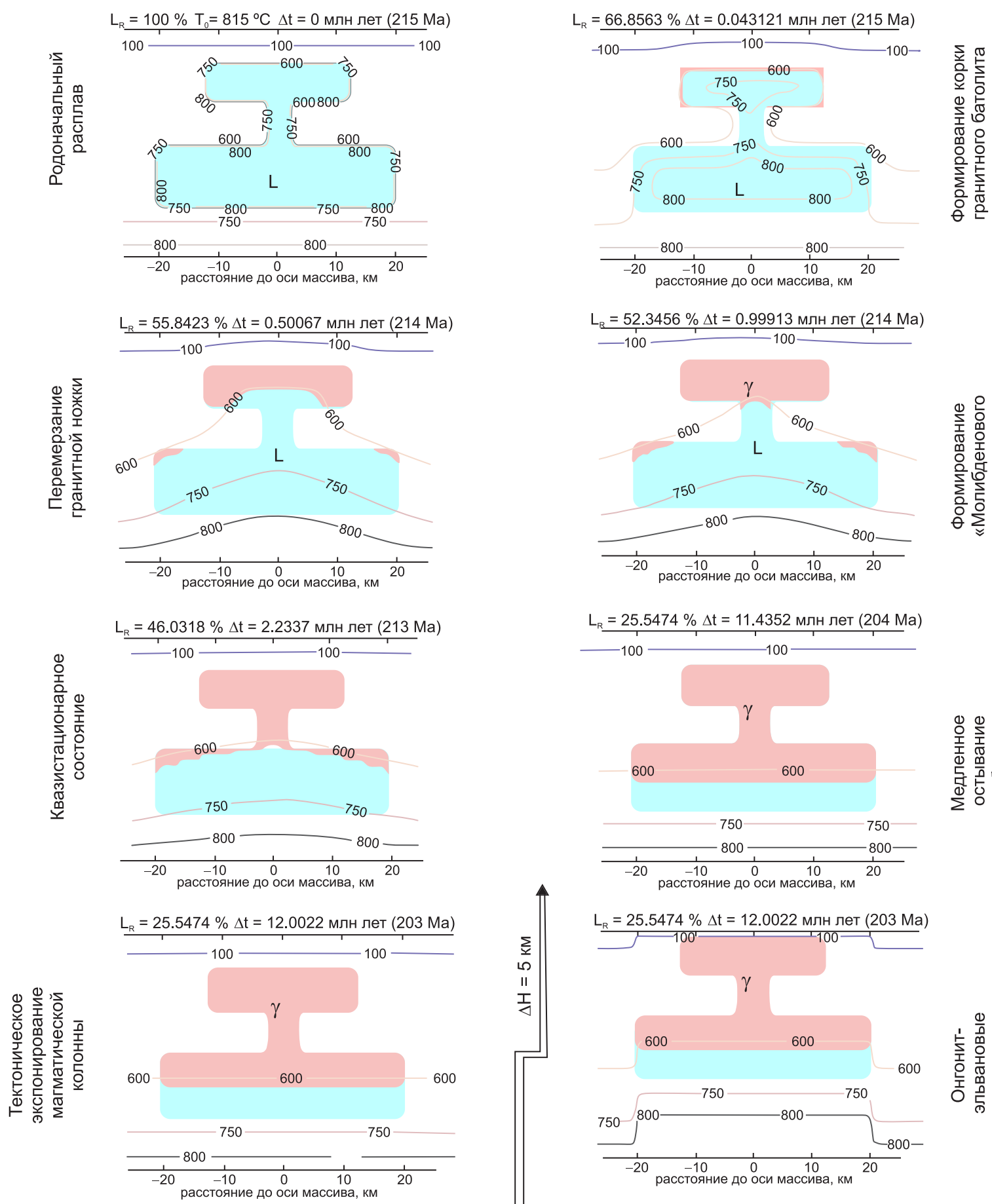

$\mathrm{L}_{\mathrm{R}}=3.2421 \% \Delta \mathrm{t}=17.376$ млн лет $(198 \mathrm{Ma})$
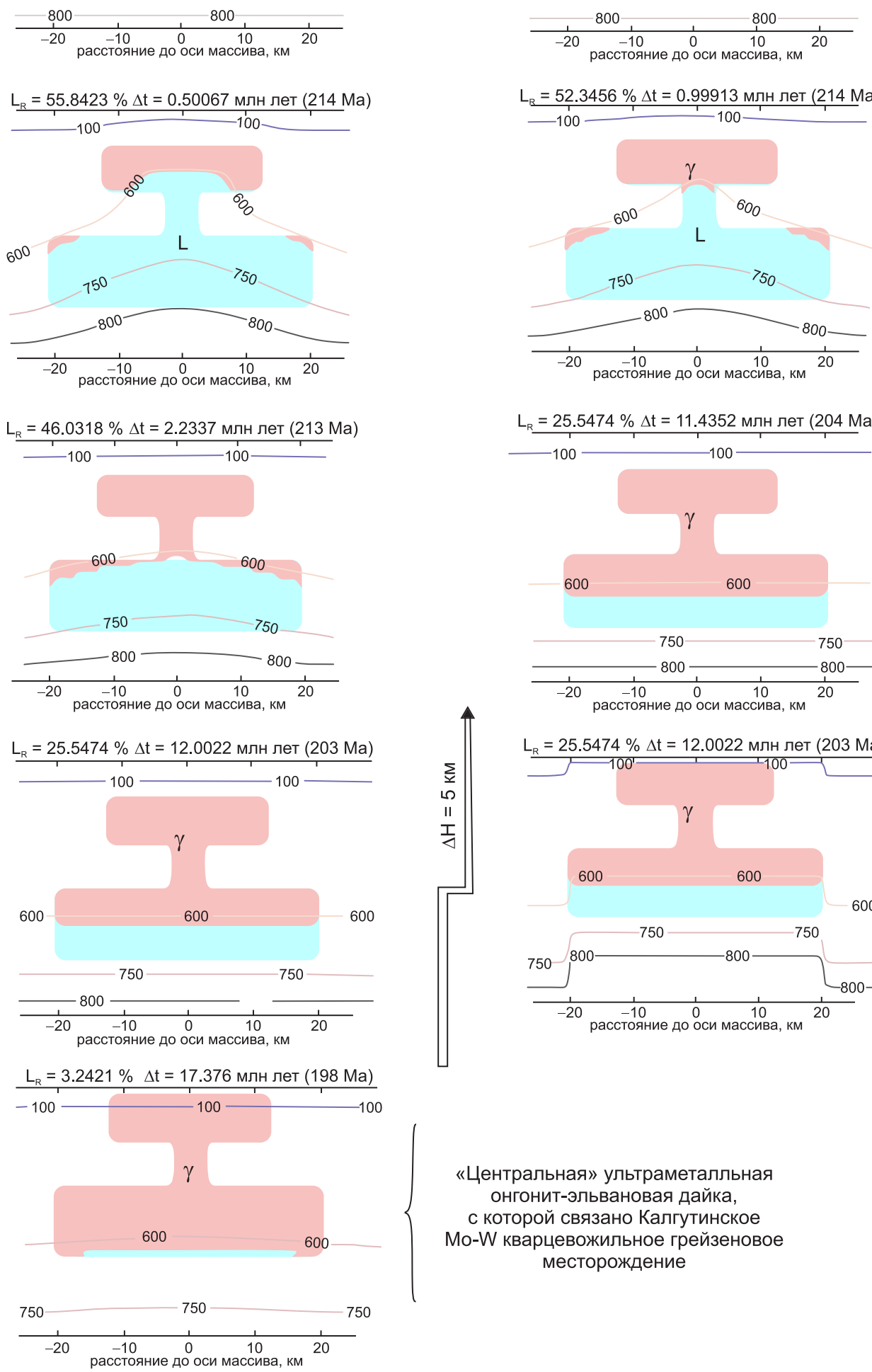

$\mathrm{L}_{\mathrm{B}}=52.3456 \% \Delta \mathrm{t}=0.99913 \mathrm{млн} \mathrm{лет}(214 \mathrm{Ma})$
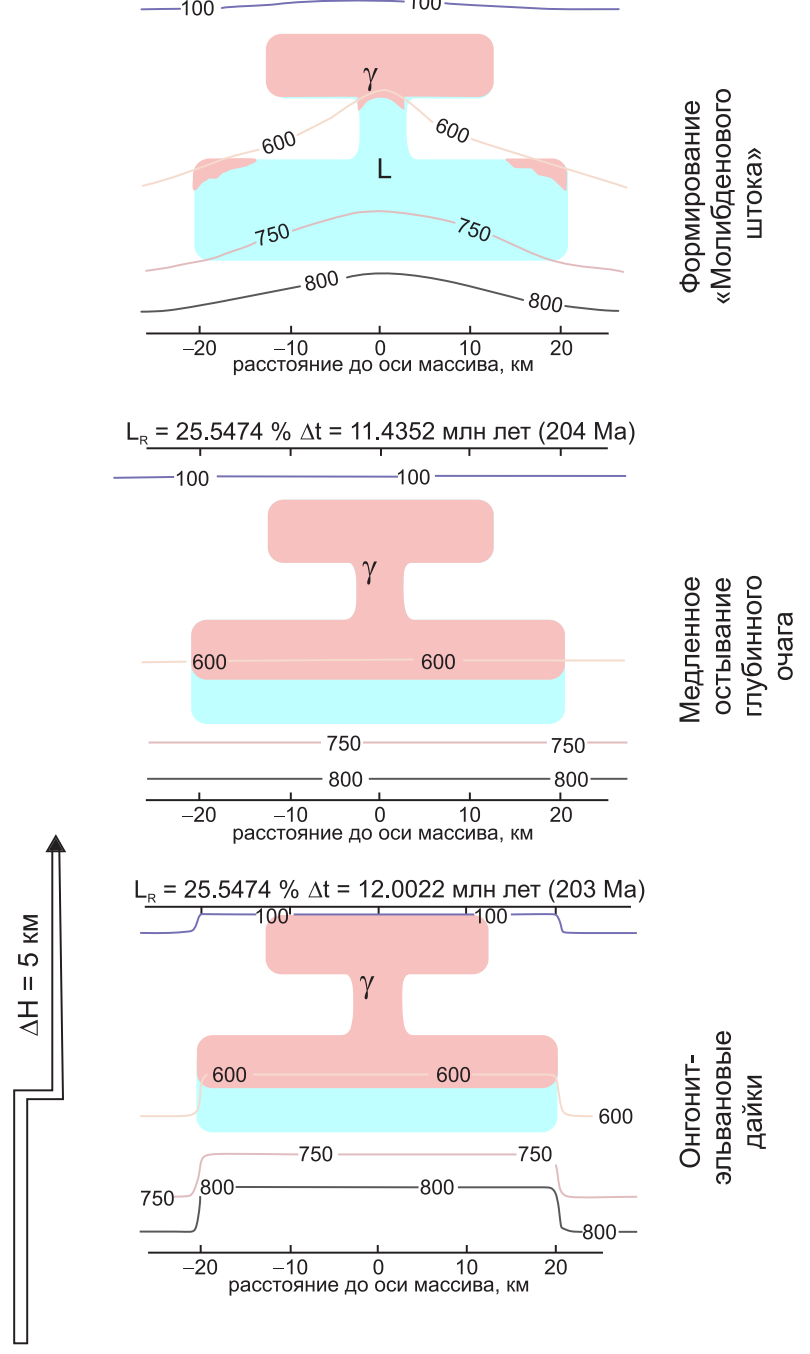

«Центральная» ультраметалльная онгонит-эльвановая дайка,

с которой связано Калгутинское

Mo-W кварцевожильное грейзеновое месторождение

Рис. 10. Геотермика и динамика остывания Калгутинской PMC (двухкаскадная модель с тектоническим взбросом). Пояснения в тексте.

Fig. 10. Geothermal features and dynamics of cooling of the Kalguty OMS (two-stage model with tectonic uplift). Explanations in the text. 

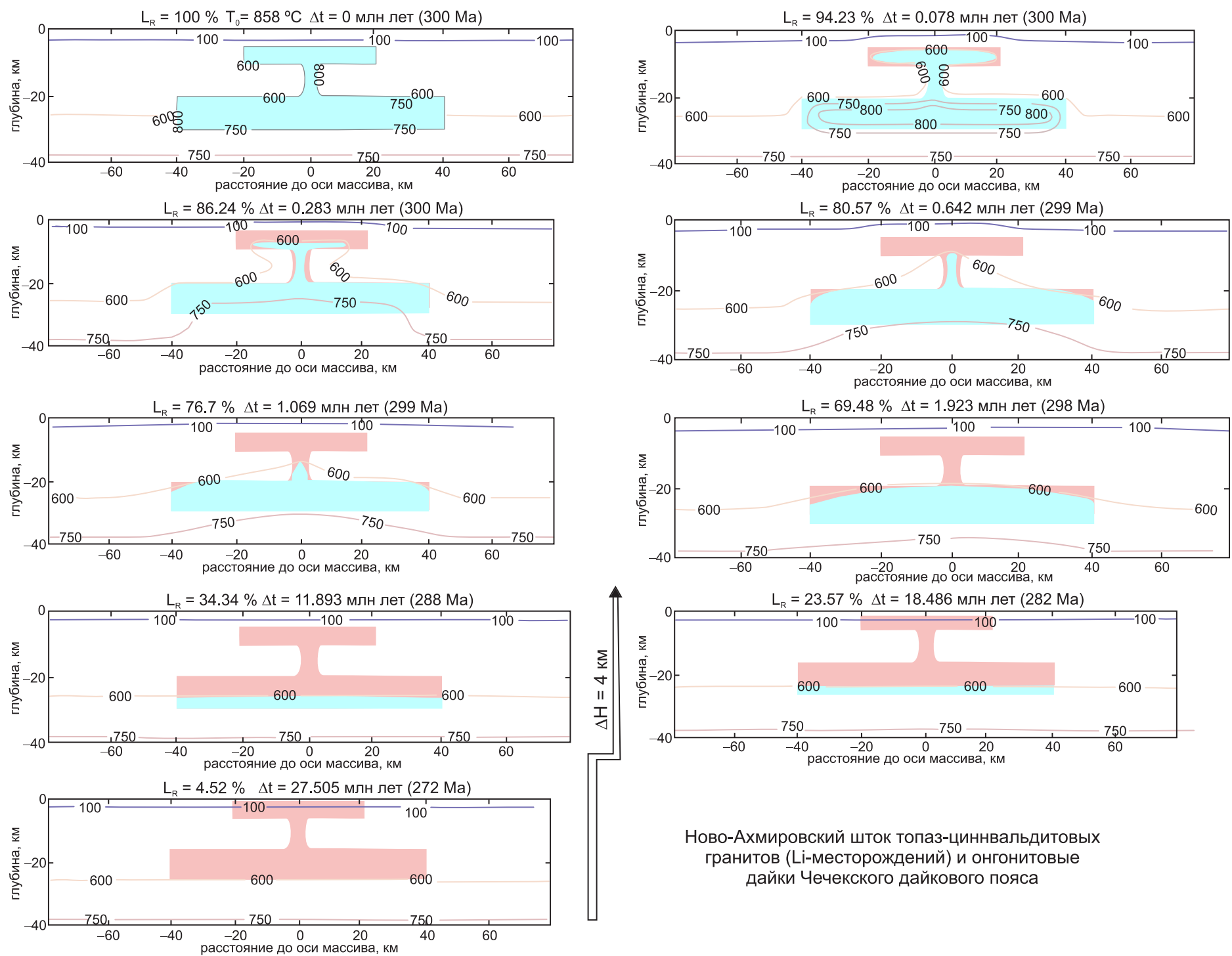

Ново-Ахмировский шток топаз-циннвальдитовых гранитов (Li-месторождений) и онгонитовые дайки Чечекского дайкового пояса

Рис. 11. Геотермика и динамика остывания Ново-Ахмировской РМС (двухкаскадная модель с тектоническим взбросом). Пояснения в тексте.

Fig. 11. Geothermal features and dynamics of cooling of the Novo-Akhmirov OMS (two-stage model with tectonic uplift).

Explanations in the text.

\section{6. ЗАКЛЮЧЕНИЕ}

Термохронологическое исследование $(\mathrm{U} / \mathrm{Pb}$, $\mathrm{Rb} / \mathrm{Sr}, \mathrm{Re} / \mathrm{Os}, \mathrm{Ar} / \mathrm{Ar}$ ) и математическое моделирование термической истории Калгутинской РMC позволяют утверждать, что формирование гранитного батолита $(215 \pm 1$ млн лет) и оторванного во времени онгонит-эльванового дайкового комплекса с богатым Mo-W оруденением $(195 \pm 1$ млн лет) может быть объяснено в варианте двухкаскадной магматической колонны, в которой существует «верхний» гранитный батолит на глубине 10-15 км и «нижний» гранитный очаг на глубине 20-30 км, связанные между собой гранитной ножкой (подводящим каналом).
Термохронологическое исследование $(\mathrm{U} / \mathrm{Pb}$, $\mathrm{Rb} / \mathrm{Sr}, \mathrm{Ar} / \mathrm{Ar}$ ) и математическое моделирование термической истории Калба-Нарымского батолита позволяют утверждать, что формирование родоначальной гранитной магмы (300-295 млн лет) и оторванных во времени литий-фтористых гранитов Ново-Ахмировского штока $(272 \pm 2$ млн лет), а также онгонит-эльвановых и лампрофировых дайковых комплексов (272-267 млн лет) можно объяснить только в варианте двухкаскадной магматической колонны, в которой существует «верхний» гранитоидный батолит на глубине 5-10 км и «нижний» гранитный слой на глубине 15-20 км, связанные между собой гранитными ножками (подводящими каналами). 
Сравнительный анализ термических историй Калгутинской и Ново-Ахмировской РМС, входящих в состав Алтайской коллизионной системы, позволяет утверждать, что на постколлизионной стадии тектогенеза (пермь - триас) были сформированы сложнопостроенные (двухкаскадные) магматические колонны, которые длительное время $(\Delta t>10$ млн лет) находились в квазистационарном состоянии.

Результаты термохронологических исследований и численного моделирования показывают реалистичность двухкаскадной модели РМС, а следовательно, позволяют поставить вопрос о длительности существования родоначальных гранитных магм на глубинных уровнях земной коры $(\geq 20$ млн лет) и перейти на этой основе к разработке термохронологических критериев глубинного прогнозирования редкометалльных месторождений.

Математическое моделирование термических историй кристаллизации и остывания гранитных батолитов в совокупности с данными комплексного изотопного датирования может послужить мощным инструментом в интерпретации геологической истории формирования рудно-магматических систем.

\section{7. БЛАГОДАРНОСТИ}

Авторы выражают искреннюю благодарность за многолетнее обсуждение поднятых проблем д.г.-м.н. А.С. Борисенко, д.г.-м.н. В.А. Пономарчуку, д.г.-м.н. Н.Н. Круку, д.г.-м.н. Е.М. Сапаргалиеву, д.г.м.н. С.З. Смирнову, а также за участие в совместных экспедиционных работах и авторские результаты геологических и геохронологических исследований, любезно предоставленные для совместного анализа, - д.г.-м.н. Г.Г. Павловой, к.г.-М.н. А.Н. Берзиной, к.г.-М.н. Д.С. Юдину, к.г.-м.н. С.В. Хромых, к.г.м.н. Е.Н. Соколовой, к.г.-м.н. П.Д. Котлеру, к.г.-м.н. О.Н. Кузьминой, Е.И. Михееву, С.А. Выставному и О.П. Герасимову. Необходимо отметить исключительно большой вклад в изучение Калгутинской PMC д.г.-м.н. А.А. Оболенского, к.г.-м.н. А.В. Титова, к.г.-м.н. В.Б. Дергачева, без материалов которых написание этой статьи было бы невозможным. Техническую помощь в подготовке и оформлении статьи оказали Т.В. Мирясова и О.Ю. Дубровина.

Работа выполнена по государственному заданию ИГМ СО РАН при финансовой поддержке Министерства науки и высшего образования Российской Федерации: проект № 5.1688.2017/ПЧ (численное моделирование), проект № 14.Y26.31.0012 (формирование компьютерной графики и построение петрологических моделей РМС), а также РФФИ - проект № 16-05-00128a $\left({ }^{40} \mathrm{Ar} /{ }^{39} \mathrm{Ar}\right.$ изотопные исследования пород и руд Калгутинской РМС и гранитов Ново-Ахмировского штока), № 17-05-00936а (интерпретация данных геохронологических исследований, термохронологический анализ, математическое моделирование).

\section{8. ЛИTEPATУРA / REFERENCES}

Annikova I.Yu., Borisenko A.S., Borovikov A.A., Goverdovskiy V.A., Kruk N.N., Naumov E.A., Obolenskiy A.A., Pavlova G.G., Travin A.V., Tretyakova I.G., Vladimirov A.G., 2007. The South-Chuya ridge and the Ukok plateau (Southern part of Gorny Altai). In: Metallogeny of the Southern Altai (Russia) and Northwestern Mongolia ore district, PermianTriassic boundary. Guidebook of field excursion. London-Novosibirsk, 63-77.

Annikova I.Yu., Smirnov S.Z., Sokolova E.N., Khromykh S.V., Vladimirov A.G., Travin A.V., 2014. Evolution of magma chamber during formation of the East-Kalguty belt of rare-metal granite porphyry dykes (Southern Altai). In: Granites and Earth's evolution: granites and continental crust. Proceedings of the 2nd International Geological Conference (Novosibirsk, Russia, 17-20 August 2014). Publishing House of SB RAS, Novosibirsk, p. 15-19 (in Russian) [Анникова И.Ю., Смирнов С.з., Соколова Е.Н., С.В. Хромых, Владимиров А.Г., Травин А.В. Эволюция очага магмы при формировании Восточно-Калгутинского редкометалльно-гранитоидного дайкового пояса (Горный Алтай) // Граниты и эволюция Земли: Материалы Второй международной геологической конференции (17-20 августа 2014 г., г. Новосибирск). Новосибирск: Изд-во СО РАН, 2014. С. 15-19].

Annikova I.Yu., Vladimirov A.G., Smirnov S.Z., Gavryushkina O.A., 2016. Geology and mineralogy of the Alakha Spodumene Granite Porphyry Deposit, Gorny Altai, Russia. Geology of Ore Deposits 58 (5), 404-426. https://doi.org/ 10.1134/S1075701516050020.

Annikova I.Yu., Vladimirov A.G., Smirnov S.Z., Oytseva T.A., Mikheev E.I., Jess E.N., Travin A.V., Dyachkov B.A., Maslov V.I., Gertner I.F., 2019. Geology and mineralogy of the Novo-Akhmirovsky lithium topaz-zinnwaldite granite deposit (Eastern Kazakhstan). Litosfera (Lithosphere) 19 (2), 304-326 (in Russian) [Анникова И.Ю., Владимиров А.Г., Смирнов С.З., Ойцева Т.А., Михеев Е.И., Джес Е.Н., Травин А.В., Дьячков Б.А., Маслов В.И., Гертнер И.Ф. Геология и минералогия Ново-Ахмировского месторождения литиевых топаз-циннвальдитовых гранитов (Восточный Казахстан) // Литосфера. 2019. Т. 19. № 2. С. 304-326].

Annikova I.Yu., Vladimirov A.G., Vystavnoi S.A., Vasilevsky A.N., Witte L.V., Moroz E.N., 2004. Geological and geophysical model of the formation of the Kalguty ore-magmatic system (Southern Altai). Bulletin of the Tomsk Polytechnic University 307 (4), 38-42 (in Russian) [Анникова И.Ю., Владимиров А.Г., Выставной С.А., Василевский А.Н., Витте Л.В., Мороз Е.Н. Геолого-геофизическая модель формирования Калгутинской рудно-магматической системы (Южный Алтай) // Известия Томского политехнического университета. 2004. T. 307. № 4. С. 38-42]. 
Annikova I.Yu., Vladimirov A.G., Vystavnoi S.A., Zhuravlev D.Z., Kruk N.N., Lepekhina E.N., Matukov D.I., Moroz E.N., Palesskii S.V., Ponomarchuk V.A., Rudnev S.N., Sergeev S.A., 2006. U-Pb and ${ }^{39} \mathrm{Ar} /{ }^{40} \mathrm{Ar}$ dating and Sm-Nd and $\mathrm{Pb}-\mathrm{Pb}$ isotopic study of the Kalguty molybdenum-tungsten ore-magmatic system, Southern Altai. Petrology 14 (1), 81-97. https://doi.org/10.1134/S0869591106010073.

Antipin V., Gerel O., Perepelov A., Odgerel D., Zolboo T., 2016. Late Paleozoic and Early Mesozoic rare-metal granites in Central Mongolia and Baikal region: review of geochemistry, possible magma sources and related mineralization. Journal of Geosciences 61 (1), 105-125. https://doi.org/10.3190/jgeosci.211.

Antipin V.S., Kushch L.V., Sheptyakova N.V., Vladimirov A.G., 2018. Geochemical evolution of the early Paleozoic collisional magmatism from autochthonous migmatites and granitoids to multiphase granite intrusions (Sharanur and Aya complexes, Baikal Region). Russian Geology and Geophysics 59 (12), 1616-1625. https://doi.org/10.1016/ j.rgg.2018.12.007.

Berzin N.A., Kungurtsev L.V., 1996. Geodynamic interpretation of geological complexes of the Altai-Sayan Region. Geologiya i Geofizika (Russian Geology and Geophysics) 37 (1), 63-81 (in Russian) [Берзин Н.А., Кунгурцев Л.В. Геодинамическая интерпретация геологических комплексов Алтае-Саянской области // Геология и геофизика. 1996. Т. 37. № 1. С. 63-81].

Berzina A.N., Stein H.J., Zimmerman A., Sotnikov V.I., 2003. Re-Os ages for molybdenite from porphyry Cu-Mo and greisen Mo-W deposits of southern Siberia (Russia) preserve metallogenic record. In: Mineral exploration and sustainable development. Proceedings of the seventh biennial SGA meeting (Athens, Greece, 24-28 august, 2003). Millpress, Rotterdam, Vol. 1, p. 231-234.

Buslov M.M., Geng H., Travin A.V., Otgonbaatar D., Kulikova A.V., Chen Ming, Stijn G., Semakov N.N., Rubanova E.S., Abildaeva M.A., Voitishek E.E., Trofimova D.A., 2013. Tectonics and geodynamics of Gorny Altai and adjacent structures of the Altai-Sayan folded area. Russian Geology and Geophysics 54 (10), 1250-1271. https://doi.org/ 10.1016/j.rgg.2013.09.009.

Buslov M.M., Watanabe T., Smirnova L.V., Fujiwara I., Iwata K., de Grave I., Semakov N.N., Travin A.V., Kiriyanova A.P., Kokh D.A., 2003. Role of strike-slip faulting in Late Paleozoic - Early Mesozoic tectonics and geodynamics of the Altai-Sayan and East Kazakhstan regions. Geologiya i Geofizika (Russian Geology and Geophysics) 44 (1-2), 47-71.

Cobbing E.J., Mallick D.I.J., Pitfield P.E.J., Teoh L.H., 1986. The granites of the Southeast Asian tin belt. Journal of the Geological Society 143 (3), 537-550. https://doi.org/10.1144/gsjgs.143.3.0537.

Darbyshire D.P.F., Shepherd T.J., 1994. Nd and Sr isotope constraints on the origin of the Cornubian batholith, SW England. Journal of the Geological Society 151 (5), 795-802. https://doi.org/10.1144/gsjgs.151.5.0795.

Dergachev V.B., 1988. A new variety of ongonites. Doklady AN SSSR 302 (1), 188-191 (in Russian) [Дергачев В.Б. Новая разновидность онгонитов // Доклады АН СССР. 1988. Т. 302. № 1. С. 188-191].

Dergachev V.B., 1989. Patterns of formation of rare metal granitic dikes. In: L.M. Balashova (Ed.), Prediction of mineralization of rare metals and gold in the Altai-Sayan folded area. Publishing House of SNIIGGiMS, Novosibirsk, p. 60-70 (in Russian) [Дергачев В.Б. Закономерности формирования редкометалльных гранитных даек // Прогнозирование оруденения редких металлов и золота в Алтае-Саянской складчатой области / Ред. Л.М. Балашова. Новосибирск: СНИИГГиМС, 1989. С. 60-70].

Dergachev V.B., Timofeev N.I., Ladygina I.N., 1981. Zonality of the Kalgutinsky molybdenum-tungsten deposit. In: N.N. Amshinsky (Ed.), Zonality of ore deposits of Siberia. Publishing House of SNIIGGiMS, Novosibirsk, p. 84-92 (in Russian) [Дергачев В.Б., Тимофеев Н.И., Ладыгина И.Н. Зональность Калгутинского молибден-вольфрамового месторождения // Зональность рудных месторождений Сибири / Ред. Н.Н. Амшинский. Новосибирск: СНИИГГиМС, 1981. С. 84-92].

Dobretsov N.L., Vladimirov A.G., Kruk N.N., 2005. Permian-Triassic magmatism in the Altai-Sayan fold system as a reflection of the Siberian superplume. Doklady Earth Sciences 400 (1), 40-43.

Dodson M.H., 1973. Closure temperature in cooling geochronological and petrological systems. Contributions to Mineralogy and Petrology 40 (3), 259-274. https://doi.org/10.1007/BF00373790.

Dovgal V.N., Distanova A.N., Sabotovich S.A., Palessky S.V., Titov A.V., Chupin V.P., Maslov V.I., Kozlov M.S., 1995. On the origin of the Late Paleozoic lithium-fluoric granitoids of the South-Western Altai. Geologiya i Geofizika (Russian Geology and Geophysics) 36 (3), 64-72 (in Russian) [Довгаль В.Н., Дистанова А.Н., Саботович С.А., Палесский С.В., Титов А.В., Чупин В.П., Маслов В.И., Козлов М.С. О происхождении позднепалеозойских литий-фтористых гранитоидов Юго-Западного Алтая // Геология и геофизика. 1995. Т. 36. № 3. С. 64-72].

Dyachkov B.A., 2012. Genetic Types of Rare-Metal Deposits of the Kalba-Narym Belt. EKSTU, Ust-Kamenogorsk, 130 p. (in Russian) [Дьячков Б.А. Генетические типы редкометалльных месторождений Калба-Нарымского пояса. Усть-Каменогорск: ВКГТУ, 2012. 130 с.].

Dyachkov B.A., Kuzmina O.N., Zimanovskaya N.A., Oitseva T.A., Mataibaeva I.E. Chernenko Z.I., 2017. Technology for Forecasting Gold Deposits of East Kazakhstan. EKSTU, Ust-Kamenogorsk, 67 p.

Ehlers T.A., 2005. Crustal thermal processes and the interpretation of thermochronometer data. Reviews in Mineralogy and Geochemistry 58 (1), 315-350. https://doi.org/10.2138/rmg.2005.58.12.

Ermolov P.V., 2013. Actual Problems of Isotope Geology and Metallogeny of Kazakhstan. Kazakh-Russian University, Karaganda, 223 p. (in Russian) [Ермолов П.В. Актуальные проблемы изотопной геологии и металлогении Казахстана. Караганда: Казахстанско-Российский университет, 2013. 223 с.]. 
Ermolov P.V., Izokh E.P., Ponomareva A.P., Tyan V.D., 1977. Gabbro-Granite Intrusive Series of Western Zaisan Fold System. Nauka, Siberian Branch, Novosibirsk, 245 p. (in Russian) [Ермолов П.В., Изох Э.П., Пономарева А.П., Тян В.Д. Габбро-гранитные серии западной части Зайсанской складчатой системы. Новосибирск: Изд-во CO PAH, 1977. 245 c.].

Ermolov P.V., Polyansky N.V., Dobretsov N.L., 1981. Ophiolites of the Chara Belt. In: A.A. Abdulin, E.I. Patalakha (Eds.), Ophiolites. Nauka, Alma-Ata, p. 103-178 (in Russian) [Ермолов П.В., Полянский Н.В., Добрецов Н.Л. Офиолиты Чарского пояса // Офиолиты / Ред. А.А. Абдулин, Е.И. Паталаха. Алма-Ата: Наука, 1981. С. 103-187].

Ermolov P.V., Vladimirov A.G., Izokh A.E., Polyansky N.V., Kuzybny V.S., Revyakin P.S., Bortsov V.D., 1983. Orogenic Magmatism of Ophiolitic Belts (on the Example of East Kazakhstan). Nauka, Novosibirsk, 208 p. (in Russian) [Epмолов П.В., Владимиров А.Г., Изох А.Э., Полянский Н.В., Кузебный В.С., Ревякин П.С., Борцов В.Д. Орогенный магматизм офиолитовых поясов (на примере Восточного Казахстана). Новосибирск: Наука, 1983. 208 с.].

Fleck R.J., Sutter J.F., Elliot D.H., 1977. Interpretation of discordant ${ }^{40} \mathrm{Ar} /{ }^{39} \mathrm{Ar}$ age-spectra of Mesozoic tholeiites from Antarctica. Geochimica et Cosmochimica Acta 41 (1), 15-32. https://doi.org/10.1016/0016-7037(77)90184-3.

Gavryushkina O.A., Kruk N.N., Semenov I.V., Vladimirov A.G., Kuibida Y.V., Serov P.A., 2019. Petrogenesis of PermianTriassic intraplate gabbro-granitic rocks in the Russian Altai. Lithos 326, 71-89. https://doi.org/10.1016/j.lithos. 2018.12.016.

Gavryushkina O.A., Travin A.V., Kruk N.N., 2016. The duration of the formation of Altai Permian-Triassic granitoids (according to ${ }^{40} \mathrm{Ar}-{ }^{39} \mathrm{Ar}$ isotope studies). In: Correlation of the Altaides and Uralides: magmatism, metamorphism, stratigraphy, geochronology, geodynamics and metallogeny. Materials of the third international scientific conference. Publishing House of SB RAS, Novosibirsk, p. 58-60 (in Russian) [Гаврюшкина О.А., Травин А.В., Крук Н.Н. Длительность формирования пермо-триасовых гранитоидов Алтая (по данным ${ }^{40} \mathrm{Ar}-39 \mathrm{Ar}$ изотопных исследований) // Корреляция алтаид и уралид: магматизм, метаморфизм, стратиграфия, геохронология, геодинамика и металлогения: Материалы третьей международной научной конференции. Новосибирск: Изд-во СО РАН, 2016. С. 58-60].

Gavryushkina O.A., Travin A.V., Kruk N.N., 2017. Duration of granitoid magmatism in peripheral parts of large igneous provinces (based on ${ }^{40} \mathrm{Ar} /{ }^{39} \mathrm{Ar}$ isotopic studies of Altai Permian-Triassic granitoids). Geodynamics \& Tectonophysics 8 (4), 1035-1047. https://doi.org/10.5800/GT-2017-8-4-0331.

Gonevchuk V.G., 2002. Tin-Bearing Systems of the Far East: Magmatism and Ore Genesis. Dal'nauka, Vladivostok, 300 p. (in Russian) [Гоневчук В.Г. Оловоносные системы Дальнего Востока: магматизм и рудогенез. Владивосток: Дальнаука, 2002. 300 с.].

Gusev N.I., 2011. Chronology (SHRIMP II) of magmatism in the Kalguty rare-metal-tungsten-molybdenum oremagmatic system, Gorny Altai, Russia. Geology of Ore Deposits 53 (3), 248-263. https://doi.org/10.1134/S10757 01511030032 .

Hodges K., 2003. Geochronology and thermochronology in orogenic system. In: H.D. Holland, K.K. Turekian (Eds.), Treatise on Geochemistry, vol. 3, p. 263-292. https://doi.org/10.1016/B0-08-043751-6/03024-3.

Johannes W., Holtz F., 1996. Petrogenesis and Experimental Petrology of Granitic Rocks. Springer-Verlag, Berlin, $335 \mathrm{p}$.

Khromykh S.V., Kotler P.D., Gurova A.V., Semenova D.V., 2018a. Post-orogenic dike belts of the altai collision system: geological position, composition and age. In: Correlation of the Altaides and Uralides: magmatism, metamorphism, stratigraphy, geochronology, geodynamics and metallogeny. Publishing House of SB RAS, Novosibirsk, 163-165 (in Russian) [Хромых C.В., Котлер П.Д., Гурова А.В., Семенова Д.В. Посторогенные дайковые пояса Алтайской коллизинной системы: геологическая позиция, состав и возраст // Корреляция алтаид и уралид: магматизм, метаморфизм, стратиграфия, геохронология, геодинамика и металлогения. Новосибирск: Изд-во СО PAH, 2018. C. 163-165].

Khromykh S., Kotler P., Vladimirov A., Izokh A., Kruk N., 2018b. 300-270 Ma magmatism of Eastern Kazakhstan related to the Tarim LIP. Large Igneous Provinces Commission, January 2018 LIP of the Month. Available from: http://largeigneousprovinces.org/18jan.

Khromykh S.V., Sokolova E.N., Smirnov S.Z., Travin A.V., Annikova I.Y., 2014. Geochemistry and age of rare-metal dyke belts in Eastern Kazakhstan. Doklady Earth Sciences 459 (2), 1587-1591.

Khromykh S.V., Tsygankov A.A., Kotler P.D., Navozov O.V., Kruk N.N., Vladimirov A.G., Travin A.V., Yudin D.S., Burmakina G.N., Khubanov V.B., Buyantuev M.D., Antsiferova T.N., Karavaeva G.S., 2016. Late Paleozoic granitoid magmatism of Eastern Kazakhstan and Western Transbaikalia: plume model test. Russian Geology and Geophysics 57 (5), 773-789. https:// doi.org/10.1016/j.rgg.2015.09.018.

Khromykh S.V., Tsygankov A.A., Kotler P.D., Navozov O.V., Vladimirov A.G., Travin A.V., Kruk N.N., Yudin D.S., Burmakina G.N., 2014. Correlation of Late Paleozoic granitoid magmatism of Eastern Kazakhstan and Western Transbaikalia. In: Correlation of the Altaides and Uralides: magmatism, metamorphism, stratigraphy, geochronology, geodynamics and metallogeny. Publishing House of SB RAS, Novosibirsk, p. 177-179 (in Russian) [Хромых С.В., Цыганков А.А., Котлер П.Д., Навозов О.В., Владимиров А.Г., Травин А.В., Крук Н.Н., Юдин Д.С., Бурмакина Г.Н. Корреляция позднепалеозойского гранитоидного магматизма Восточного Казахстана и Западного Забайкалья // Корреляция алтаид и уралид: магматизм, метаморфизм, стратиграфия, геохронология, геодинамика и металлогеническое прогнозирование. Новосибирск: Изд-во СО РАН, 2014. С. 177-179].

Kostitsyn Y.A., Vystavnoy S.A., Vladimirov A.G., 1998. Age and genesis of the spodumene-bearing granites of the SW Altai (Russia): an isotopic and geochemical study. Acta Universitatis Carolinae: Geologica 42 (1), 60-63. 
Kotler P.D., Khromykh S.V., Vladimirov A.G., Navozov O.V., Travin A.V., Karavaeva G.S., Kruk N.N., Murzintsev N.G., 2015. New data on the age and geodynamic interpretation of the Kalba-Narym granitic batholith, eastern Kazakhstan. Doklady Earth Sciences 462 (2), 565-569. https://doi.org/10.1134/S1028334X15060136.

Kruk N.N., 2015. Continental crust of Gorny Altai: stages of formation and evolution; indicative role of granitoids. Russian Geology and Geophysics 56 (8), 1097-1113. https://doi.org/10.1016/j.rgg.2015.07.001.

Kuibida M.L., Safonova I.Y., Yermolov P.V., Vladimirov A.G., Kruk N.N., Yamamoto S., 2016. Tonalites and plagiogranites of the Char suture-shear zone in East Kazakhstan: Implications for the Kazakhstan-Siberia collision. Geoscience Frontiers 7 (1), 141-150. https://doi.org/10.1016/j.gsf.2015.09.002.

Kuybida M.L., Kruk N.N., Vladimirov A.G., Murzin O.V., Shokalsky S.P., Gusev N.I., Kuybida I.V., Kruk E.A., Moroz E.I., Vladimirov V.G., Rudnev S.N., 2019. Geochemical characteristics and geochronology of contrasting granitoid magmatism of Ore Altai: on the issue of the transform margin of the Asian continent. Litosfera (Lithosphere) (in press) (in Russian) [Куйбида М.Л., Крук Н.Н., Владимиров А.Г., Мурзин О.В., Шокальский С.П., Гусев Н.И., Куйбида Я.В., Крук Е.А., Мороз Е.И., Владимиров В.Г., Руднев С.Н. Геохимические характеристики и геохронология контрастного гранитоидного магматизма Рудного Алтая: к вопросу о трансформной окраине Азиатского континента // Литосфера. 2019 (в печати)].

Liu F., Zhang Z.X., Li Q., Qu W.J., Li C., 2012. New age constraints on Koktokay pegmatite No. 3 Vein, Altay Mountains, Xinjiang: evidence from molybdenite Re-Os dating. Mineral Deposits 31 (5), 1111-1118 (in Chinese, with English abstract).

Lopatnikov V.V., Izokh E.P., Ermolov P.V., Ponomareva A.P., Stepanov A.E., 1982. Magmatism and Ore Content of the Kalba-Narym Zone of East Kazakhstan. Nauka, Moscow, 247 p. (in Russian) [Лопатников В.В., Изох Э.П., Ермолов П.В., Пономарева А.П., Степанов А.Е. Магматизм и рудоносность Калба-Нарымской зоны Восточного Казахстана. М.: Наука, 1982. 247 с.].

Maslov V.I., 1994. Report of the Zyryanovsk Party on the Results of Searches for Tin and Rare Metals in the Diabase Section for 1990-1994. State holding company “Topaz”, Ust-Kamenogorsk, 171 p. (in Russian) [Маслов В.И. Отчет Зыряновской партии о результатах поисков на олово и редкие металлы на участке Диабазовый за 1990-1994 гг. Усть-Каменогорск: Государственная холдинговая компания «Топаз», 1994. 171 с.].

Maslov V.I., Kozlov M.S., Dovgal V.N., Distanova A.N., 1994. Complex of ongonites and lithium fluoride granites of SouthWestern Altai. Petrologiya (Petrology) 2 (3), 331-336 (in Russian) [Маслов В.И., Козлов М.С., Довгаль В.Н., Дистанова А.Н. Комплекс онгонитов и литий-фтористых гранитов юго-западного Алтая // Петрология. 1994. T. 2. № 3. C. 331-336].

Oitseva T.A., 2018. Geology, Mineralogy and Conditions for the Formation of Rare-Metal Mineralization of East Kazakhstan. Abstract of dissertation for the degree of Doctor of Philosophy, Karaganda, 21 p. (in Russian) [Ойцева T.A. Геология, минералогия и условия формирования редкометалльного оруденения Восточного Казахстана: Автореф. дис. ... докт. философии. Караганда, 2018. 21 с.].

Oitseva T.A., Kuzmina O.N., Dyachkov B.A., Vladimirov A.G., Annikova I.Yu., 2016b. On the unconventional type of rare metal mineralization of East Kazakhstan. In: Correlation of the Altaides and Uralides: magmatism, metamorphism, stratigraphy, geochronology, geodynamics and metallogeny. Publishing House of SB RAS, Novosibirsk, p. 136-138 (in Russian) [Ойцева Т.А., Кузьмина О.Н., Дьячков Б.А., Владимиров А.Г., Анникова И.Ю. О нетрадиционном типе редкометалльного оруденения Восточного Казахстана // Корреляция алтаид и уралид: магматизм, метаморфизм, стратиграфия, геохронология, геодинамика и металлогения. Новосибирск: Изд-во СО РАН, 2016. C. 136-138].

Oitseva T.A., Kuzmina O.N., Murzintsev N.G., Kotler P.D., 2016a. Rare metal structures, mineral types and age of the pegmatite deposits of Qalba-Narym granitoid belt. In: Proceedings of the 8th International Siberian Early Career Geoscientists Conference. IGM SB RAS, IPPG SB RAS, NSU, Novosibirsk, p. 216-217.

Pavlova G.G., Borisenko A.S., Goverdovskii V.A., Travin A.V., Zhukova I.A., Tret'yakova I.G., 2008. Permian-Triassic magmatism and Ag-Sb mineralization in southeastern Altai and northwestern Mongolia. Russian Geology and Geophysics 49 (7), 545-555. https://doi.org/10.1016/j.rgg.2008.06.010.

Polyansky O.P., Sukhorukov V.P., Travin A.V., Alekhin I.G., Yudin D.S., 2011. Tectonic interpretation of the thermochronological data and PT-conditions of rock metamorphism in the Bodonchin zonal complex (Mongolian Altay). Russian Geology and Geophysics 52 (9), 991-1006. https://doi.org/10.1016/j.rgg.2011.08.005.

Potseluev A.A., Rihvanov L.P., Vladimirov A.G., Annikova I. Yu., Babkin D.I., Nikiforov A.Yu., Kotegov V.I., 2008. Kalguty RareMetal Deposit (Southern Altai): Magmatizm and Ore Formation. STT, Tomsk, 226 p. (in Russian) [Поцелуев А.A., Рихванов Л.П., Владимиров А.Г., Анникова И.Ю., Бабкин Д.И., Никифоров А.Ю., Котегов В.И. Калгутинское редкометалльное месторождение (Горный Алтай): магматизм и рудогенез. Томск: STT, 2008. 226 с.].

Roger F., Jolivet M., Cattin R., Malavieille J., 2011. Mesozoic-Cenozoic tectonothermal evolution of the eastern part of the Tibetan Plateau (Songpan-Garzê, Longmen Shan area): insights from thermochronological data and simple thermal modelling. In: R. Gloaguen, L. Ratschbacher (Eds.), Growth and collapse of the Tibetan plateau. Geological Society, London, Special Publications, vol. 353, p. 9-25. https://doi.org/10.1144/SP353.2.

Rub A.K., Rub M.G., 2006. Rare Metal Granites of Primorye. VIMS, Moscow, 86 p. (in Russian) [Руб А.К., Руб М.Г. Редкометалльные граниты Приморья. М.: ВИМС, 2006. 86 с.].

Safonova I., 2014. The Russian-Kazakh Altai orogen: An overview and main debatable issues. Geoscience Frontiers 5 (4), 537-552. https://doi.org/10.1016/j.gsf.2013.12.003. 
Savinsky I.A., 2017. Metamorphic Complexes HT/MT of the Northwestern Part of the Irtysh Crush Zone (East Kazakhstan). Author's brief thesis (Candidate of Geology and Mineralogy), IGM SB RAS, Novosibirsk, 22 p. (in Russian) [Савинский И.А. Метаморфические комплексы НТ/MТ типа северо-западной части Иртышской зоны смятия (Восточный Казахстан): Автореф. дис. ... канд. геол.-мин. наук. Новосибирск: ИГМ СО РАН, 2017. 22 с.].

Savinsky I.A., Vladimirov V.G., 2015. Chechek granite-gneiss structure (Irtysh crushing zone). Geology and mineral resources of Siberia (1), 15-22 (in Russian) [Савинский И.А., Владимиров В.Г. Чечекская гранитогнейсовая структура (Иртышская зона смятия) // Геология и минерально-сырьевые ресурсы Сибири. 2015. № 1. C. 15-22].

Seltmann R., Borisenko A., Fedoseev G. (Eds.), 2007. Magmatism and Metallogeny of the Altai and Adjected Large Igneous Provinces with an Introductory Essay on the Altaids. IAGOD Guidebook Series 16. CERCAMS/NHM, London, $294 \mathrm{p}$.

Sengör A.M.C., Natal'in B.A., Burtman V.S., 1993. Evolution of the Altaid tectonic collage and Palaeozoic crustal growth in Eurasia. Nature 364 (6435), 299-307. https://doi.org/10.1038/364299a0.

Shcherba G.N., Dyachkov B.A., Nachtigal G.P., 1984. Metallogeny of Ore Altai and Kalba, Nauka, Alma-Ata, 239 p. (in Russian) [Щерба Г.Н., Дьячков Б.А., Нахтигаль Г.П. Металлогения Рудного Алтая и Калбы. Алма-Ата: Наука, 1984. 239 с.].

Shcherba G.N., Dyachkov B.A., Stuchevsky N.I., Nachtigal G.P., Antonenko A.N., Lyubetsky V.N., 1998. Great Altai (Geology and Metallogeny). Gylym, Almaty, 304 p. (in Russian) [Щерба Г.Н., Дьячков Б.А., Стучевский Н.И., Нахтигаль Г.П., Антоненко А.Н., Любецкий В.Н. Большой Алтай (геология и металлогения). Алматы: Гылым, 1998. 304 с.].

Shokalsky S.P., Babin G.A., Vladimirov A.G., Borisov S.M., Gusev N.I., Tokarev V.N., Zybin V.A., Dubskiy V.S., Murzin O.V., Krivchikov V.A., Kruk N.N., Rudnev S.N., Fedoseyev G.S., Titov A.V., Sergeyev V.P., Likhachev N.N., Mallin A.N., Kotelnikov Ye.I., Kuznetsov S.A., Zeyfert L.L., Yashin V.D., Noskov Yu.S., Uvarov A.N., Fedak S.I., Gusev A.I., Vystavnoi S.A., 2000. Correlation of Magmatic and Metamorphic Complexes of the Western Part of the Altai-Sayan Folded Region. Publishing House of SB RAS, Novosibirsk, 120 p. (in Russian] [Шокальский С.П., Бабин Г.А., Владимиров А.Г., Борисов С.М., Гусев Н.И., Токарев В.Н., Зыбин В.А., Дубский В.С., Мурзин О.В., Кривчиков В.А., Крук Н.Н., Руднев С.Н., Федосеев Г.С., Титов А.В., Сергеев В.П., Лихачев Н.Н., Маллин А.Н., Котельников Е.И., Кузнецов С.А., Зейферт Л.Л., Яшин В.Д., Носков Ю.С., Уваров А.Н., Федак С.И., Гусев А.И., Выставной С.А. Корреляция магматических и метаморфических комплексов западной части Алтае-Саянской складчатой области. Новосибирск: Изд-во СО РАН, филиал «Гео», 2000. 120 с.].

Sokolova E., Smirnov S., Annikova I., 2011. Compositions of magmatic melts at formation of chemically heterogeneous rare-metal felsic dike in the East Kalguty dike belt (Gorny Altai, Russia). In: ECROFI-XXI, European current research on fluid inclusions (Montan universitat, Leoben, Austria, 9-11 August, 2011). Abstracts. Leoben, p. $174-175$.

Sokolova E.N., Smirnov S.Z., Astrelina E.I., Annikova I.Y., Vladimirov A.G., Kotler P.D., 2011. Ongonite-elvan magmas of the Kalguty ore-magmatic system (Gorny Altai): composition, fluid regime, and genesis. Russian Geology and Geophysics 52 (11), 1378-1400. https://doi.org/10.1016/j.rgg.2011.10.017.

Štemprok M., Pivec E., Langrová A., 2005. The petrogenesis of a wolframite-bearing greisen in the Vykmanov granite stock, Western Krušné hory pluton (Czech Republic). Bulletin of Geosciences 80 (3), 163-184.

Tauson L.V., 1977. Geochemical Types and Potential Ore-Bearing Granitoids. Nauka, Moscow, 280 p. (in Russian) [Таусон Л.В. Геохимические типы и потенциальная рудоносность гранитоидов. М.: Наука, 1977. 280 с.].

Titov A.V., Vladimirov A.G., Vystavnoi S.A., Pospelova L.N., 2001. Extraordinary high-temperature felsite porphyries in the postgranite dike swarm of the Kalguty rare-metal granite massif, Gornyi Altai Mountains. Geochemistry International 39 (6), 615-620.

Travin A.V., 2016. Thermochronology of Early Paleozoic collisional and subduction-collisional structures of Central Asia. Russian Geology and Geophysics 57 (3), 434-450. https://doi.org/10.1016/j.rgg.2016.03.006.

Travin A.V., Boven A., Plotnikov A.V., Vladimirov V.G., Theunissen K., Vladimirov A.G., Melnikov A.G., Titov A.V., 2001. ${ }^{40} \mathrm{Ar} /{ }^{39} \mathrm{Ar}$ dating of ductile deformations in the Irtysh shear zone, Eastern Kazakhstan. Geochemistry International 39 (12), 1237-1241.

Travin A.V., Vladimirov V.G., Murzintsev N.G., Savinsky I.A., 2016. Thermochronology of the Irtysh shift zone (Central Asia). In: Correlation of the Altaides and Uralides: magmatism, metamorphism, stratigraphy, geochronology, geodynamics and metallogeny. Publishing House of SB RAS, Novosibirsk, p. 184-186 (in Russian) [Травин А.В., Владимиров В.Г., Мурзинщев Н.Г., Савинский И.А., 2016. Термохронология Иртышской сдвиговой зоны (Центральная Азия) // Корреляция алтаид и уралид: магматизм, метаморфизм, стратиграфия, геохронология, геодинамика и металлогения. Новосибирск: Изд-во СО РАН, С. 184-186].

Vasyukova E.A., Izokh A.E., Borisenko A.S., Pavlova G.G., Sukhorukov V.P., Anh T.T., 2011. Early Mesozoic lamprophyres in Gorny Altai: petrology and age boundaries. Russian Geology and Geophysics 52 (12), 1574-1591. https://doi.org/ 10.1016/j.rgg.2011.11.010.

Vigneresse J.L., 2015. Textures and melt-crystal-gas interactions in granites. Geoscience Frontiers 6 (5), 635-663. https://doi.org/10.1016/j.gsf.2014.12.004.

Vladimirov A.G., Annikova I.Yu., Murzintsev N.G., Travin A.V., Sokolova E.N., Smirnov S.Z., Gavryushkina O.A., Oitseva T.A., 2019. Age stages and an estimation of formation time for the Kalguta molybdenum-tungsten ore-magmatic system (Altai): thermochronology and mathematical modeling. Russian Geology and Geophysics (in press). 
Vladimirov A.G., Kosarev A.M., Khanchuk A.I., Salikhov D.N., Kruk N.N., Safonova I.Yu., Gaskov I.V., Dyachkov B.A., Khromykh S.V., Annikova I.Yu., Kuybida M.L., Seravkin I.B., Gertner I.F., Kotler P.D., Rakhimov I.R., Kuzmina O.N., Oytseva T.A., 2016. Correlation and Geodynamic Interpretation of Igneous Events and mineralization of the Southern Urals and Altai (Middle - Late Paleozoic). Preprint No. 1/16. Publishing House of SB RAS, Novosibirsk, 51 p. (in Russian] [Владимиров А.Г., Косарев А.М., Ханчук А.И., Салихов Д.Н., Крук Н.Н., Сафонова И.Ю., Гаськов И.В., Дьячков Б.А., Хромых С.В., Анникова И.Ю., Куйбида М.Л., Серавкин И.Б., Гертнер И.Ф., Котлер П.Д., Рахимов И.Р., Кузьмина О.Н., Ойцева Т.A. Корреляция и геодинамическая интерпретация магматических событий и оруденения Южного Урала и Алтая (средний - поздний палеозой). Препринт № 1/16. Новосибирск: Изд-во СО РАН, 2016. 51 c.].

Vladimirov A.G., Kozlov M.S., Shokal'skii S.P., Khalilov V.A., Rudnev S.N., Kruk N.N., Vystavnoi S.A., Borisov S.M., Berezikov Yu.K., Metzner A.N., Babin G.A., Mamlin A.N., Murzin O.M., Nazarov G.V., Makarov V.A., 2001. The major age epochs of intrusive magmatism of Kuznetsk Alatau, Altai and Kalba (from U-Pb isotope dates). Geologiya i Geofizika (Russian Geology and Geophysics) 42 (8), 1149-1170.

Vladimirov A.G., Kruk N.N., Khromykh S.V., Polyansky O.P., Chervov V.V., Vladimirov V.G., Travin A.V., Babin G.A., Kuibida M.L., Khomyakov V.D., 2008. Permian magmatism and lithospheric deformation in the Altai caused by crustal and mantle thermal processes. Russian Geology and Geophysics 49 (7), 468-479. https://doi.org/10.1016/j.rgg.2008.06.006.

Vladimirov A.G., Kruk N.N., Rudnev S.N., Khromykh S.V., 2003. Geodynamics and granitoid magmatism of collisional orogens. Geologiya i Geofizika (Russian Geology and Geophysics) 44 (12), 1275-1292.

Vladimirov A.G., Lyakhov N.Z., Zagorskiy V.E., Makagon V.M., Kuznetsova L.G., Smirnov S.Z., Isupov V.P., Belozerov I.M., Uvarov A.N., Gusev G.S., Yusupov T.S., Annikova I.Yu., Beskin S.M., Shokalskiy S.P., Mikheev E.I., Kotler P.D., Moroz E.N., Gavryushkina O.A., 2012. Lithium deposits of spodumene pegmatites in Siberia. Chemistry for Sustainable Development 20 (1), 3-20 (in Russian) [Владимиров А.Г., Ляхов Н.З., Загорский В.Е., Макагон В.М., Кузнецова Л.Г., Смирнов С.З., Исупов В.П., Белозеров И.М., Уваров А.Н., Гусев Г.С., Юсупов Т.С., Анникова И.Ю., Бескин С.М., Шокальский С.П., Михеев Е.И., Котлер П.Д., Мороз Е.Н., Гаврюшкина О.А. Литиевые месторождения сподуменовых пегматитов Сибири // Химия в интересах устойчивого развития. 2012. Т. 20. № 1. С. 3-20].

Vladimirov A.G., Ponomareva A.P., Shokalskii S.P., Khalilov V.A., Kostitsyn Y.A., Ponomarchuk V.A., Rudnev S.N., Vystavnoi S.A., Kruk N.N., Titov A.V., 1997. Late Paleozoic - Early Mesozoic granitoid magmatism in Altai. Geologiya i Geofizika (Russian Geology and Geophysics) 38 (4), 715-729.

Vladimirov A.G., Vystavnoi S.A., Titov A.V., Rudnev S.N., Dergachev V.A., Annikov I.Yu., Tikunov Yu.V., 1998. Petrology of the Early Mesozoic rare-metal granites of the southern Gorny Altai. Geologiya i Geofizika (Russian Geology and Geophysics) 39 (7), 901-916.

Vrublevskii V.V., Gertner I.F., Polyakov G.V., Izokh A.E., Krupchatnikov V.I., Travin A.V., Voitenko N.N., 2004. Ar-Ar isotopic age of lamproite dikes of the Chua complex, Gorny Altai. Doklady Earth Sciences 399A (9), 1252-1255.

Wang D.H., Chen Y.C., Xu Z.G., Li T.D., Fu X.J., 2002. The ore-forming series and law in Altay ore-forming province Yuanzineng Publish House, Beijing, 493 p. (in Chinese).

Windley B.F., Alexeiev D., Xiao W., Kröner A., Badarch G., 2007. Tectonic models for accretion of the Central Asian Orogenic Belt. Journal of the Geological Society 164 (1), 31-47. https://doi.org/10.1144/0016-76492006-022.

Zagorsky V.E., Vladimirov A.G., Makagon V.M., Kuznetsova L.G., Smirnov S.Z., D'yachkov B.A., Annikova I.Yu., Shokalsky S.P., Uvarov A.N., 2014. Large fields of spodumene pegmatites in the settings of rifting and postcollisional shear-pull-apart dislocations of continental lithosphere. Russian Geology and Geophysics 55 (2), 237-251. https://doi.org/10.1016/ j.rgg.2014.01.008.

Zhu Y. F., Zeng Y., Gu L., 2006. Geochemistry of the rare metal-bearing pegmatite No. 3 vein and related granites in the Keketuohai region, Altay Mountains, northwest China. Journal of Asian Earth Sciences 27 (1), 61-77. https:// doi.org/10.1016/j.jseaes.2005.01.007.

\section{Николай Геннадьевич Мурзинцев}

Институт геологии и минералогии им. В.С. Соболева СО РАН

630090, Новосибирск, пр. Академика Коптюга, 3, Россия

\section{Nikolai G. Murzintsev}

V.S. Sobolev Institute of Geology and Mineralogy, Siberian Branch of RAS 3 Academician Koptyug ave., Novosibirsk 630090, Russia

凶 e-mail: murzintsevng@gmail.com 


\section{Ирина Юрьевна Анникова}

канд. геол.-мин. наук

Институт геологии и минералогии им. В.С. Соболева СО РАН 630090, Новосибирск, пр. Академика Коптюга, 3, Россия

Новосибирский национальный исследовательский государственный университет

630090, Новосибирск, ул. Пирогова, 2, Россия

Томский государственный университет

634050, Томск, пр. Ленина, 50, Россия

e-mail: ira99@igm.nsc.ru

(iD) https://orcid.org/0000-0002-0045-4091

\section{Алексей Валентинович Травин}

докт. геол.-мин. наук

Институт геологии и минералогии им. В.С. Соболева СО РАН 630090, Новосибирск, пр. Академика Коптюга, 3, Россия

Новосибирский национальный исследовательский государственный университет

630090, Новосибирск, ул. Пирогова, 2, Россия

Томский государственный университет

634050, Томск, пр. Ленина, 50, Россия

e-mail: travin@igm.nsc.ru

(iD) https://orcid.org/0000-0002-5640-4560

\section{Александр Геннадьевич Владимиров}

докт. геол.-мин. наук, профессор

Институт геологии и минералогии им. В.С. Соболева СО РАН 630090, Новосибирск, пр. Академика Коптюга, 3, Россия

Новосибирский национальный исследовательский государственный университет

630090, Новосибирск, ул. Пирогова, 2, Россия

Томский государственный университет

634050, Томск, пр. Ленина, 50, Россия

e-mail: vladimir@igm.nsc.ru

(iD) https://orcid.org/0000-0001-7884-2601

\section{Борис Александрович Дьячков}

докт. геол.-мин. наук, академик НАН Республики Казахстан

Восточно-Казахстанский государственный технический

университет им. Д. Серикбаева

070004, Усть-Каменогорск, ул. Протозанова, 69,

Республика Казахстан

ТОО Алтайский геолого-экологический институт им. К.И. Сатпаева 070004, Усть-Каменогорск, ул. Карла Либкнехта, 21,

Республика Казахстан

e-mail: bdyachkov@mail.ru

\section{Владимир Иванович Маслов}

ведущий геолог

TOO GEO.KZ

070004, Усть-Каменогорск, проспект Победы, 3/2,

Республика Казахстан

\section{Irina Yu. Annikova}

Candidate of Geology and Mineralogy

V.S. Sobolev Institute of Geology and Mineralogy, Siberian Branch of RAS 3 Academician Koptyug ave., Novosibirsk 630090, Russia

Novosibirsk State University

2 Pirogov street, Novosibirsk 630090, Russia

Tomsk State University

50 Lenin ave., Tomsk 634050, Russia

\section{Aleksei V. Travin \\ Doctor of Geology and Mineralogy}

V.S. Sobolev Institute of Geology and Mineralogy, Siberian Branch of RAS 3 Academician Koptyug ave., Novosibirsk 630090, Russia

Novosibirsk State University

2 Pirogov street, Novosibirsk 630090, Russia

Tomsk State University

50 Lenin ave., Tomsk 634050, Russia

\section{Aleksander G. Vladimirov \\ Doctor of Geology and Mineralogy, Professor}

V.S. Sobolev Institute of Geology and Mineralogy, Siberian Branch of RAS 3 Academician Koptyug ave., Novosibirsk 630090, Russia

Novosibirsk State University

2 Pirogov street, Novosibirsk 630090, Russia

Tomsk State University

50 Lenin ave., Tomsk 634050, Russia

\section{Boris A. Dyachkov}

Doctor of Geology and Mineralogy, Academician of Kazakhstan Academy of Sciences

D. Serikbaev East Kazakhstan State Technical University

69 Protazanov street, Ust-Kamenogorsk 070004, Republic of Kazakhstan

LLP K.I. Satpayev Altai Geological and Environmental Institute

21 Karl Liebknecht street, Ust-Kamenogorsk 070004, Republic of Kazakhstan

\section{Vladimir I. Maslov}

Lead Geologist

LLP GEO.KZ

3/2 Pobeda ave., Ust-Kamenogorsk 070004, Republic of Kazakhstan

e-mail: tatiana.oitseva@gmail.com 
N.G. Murzintsev et al.: Thermochronology and mathematical modeling of the formation dynamics...

Татьяна Анатольевна Ойцева

ст. преподаватель

Восточно-Казахстанский государственный технический университет им. Д. Серикбаева

070004, Усть-Каменогорск, ул. Протозанова, 69,

Республика Казахстан

e-mail: tatiana.oitseva@gmail.com

\section{Ольга Александровна Гаврюшкина}

M.H.C

Институт геологии и минералогии им. В.С. Соболева СО РАН 630090, Новосибирск, пр. Академика Коптюга, 3, Россия

e-mail: o.khokhryakova@gmail.com
Tatiana A. Oitseva

Senior Lecturer

D. Serikbaev East Kazakhstan State Technical University

69 Protazanov street, Ust-Kamenogorsk 070004, Republic of Kazakhstan

\section{Olga A. Gavryushkina}

Junior Researcher

V.S. Sobolev Institute of Geology and Mineralogy, Siberian Branch of RAS 3 Academician Koptyug ave., Novosibirsk 630090, Russia 